\title{
New crystalline silicon ribbon materials for photovoltaics
}

\author{
G Hahn ${ }^{1}$ and A Schönecker ${ }^{2}$ \\ ${ }^{1}$ Department of Physics, University of Konstanz, Jakob-Burckhardt-Straße 29, 78457 Konstanz, \\ Germany \\ ${ }^{2}$ ECN Solar Energy, PO Box 1, 1755ZG Petten, Netherlands \\ E-mail: giso.hahn@uni-konstanz.de
}

\begin{abstract}
The objective of this article is to review, in relation to photovoltaic applications, the current status of crystalline silicon ribbon technologies as an alternative to technologies based on wafers originating from ingots. Increased wafer demand, the foreseeable silicon feedstock shortage, and the need for a substantial module cost reduction are the main issues that must be faced in the booming photovoltaic market. Ribbon technologies make excellent use of silicon, as wafers are crystallized directly from the melt at the desired thickness and no kerf losses occur. Therefore, they offer a high potential for significantly reducing photovoltaic electricity costs as compared to technology based on wafers cut from ingots. However, the defect structure present in the ribbon silicon wafers can limit material quality and cell efficiency.

We will review the most successful of the ribbon techniques already used in large scale production or currently in the pilot demonstration phase, with special emphasis on the defects incorporated during crystal growth. Because of the inhomogeneous distribution of defects, mapped characterization techniques have to be applied. Al and $\mathrm{P}$ gettering studies give an insight into the complex interaction of defects in the multicrystalline materials as the gettering efficiency is influenced by the state of the chemical bonding of the metal atoms. The most important technique for improvement of carrier lifetimes is hydrogenation, whose kinetics are strongly influenced by oxygen and carbon concentrations present in the material. The best cell efficiencies for laboratory-type (17\%$18 \%$; cell area: $\left.4 \mathrm{~cm}^{2}\right)$ as well as industrial-type (15\%-16\%; cell area: $\geqslant 80 \mathrm{~cm}^{2}$ ) ribbon silicon solar cells are in the same range as for standard wafers cut from ingots. A substantial cost reduction therefore seems achievable, although the most promising techniques need to be improved.
\end{abstract}

(Some figures in this article are in colour only in the electronic version) 


\section{Contents}

1. Introduction 1616

1.1. Electronic characteristics 1618

$\begin{array}{lr}\text { 1.2. Impurities } & 1619\end{array}$

2. Ribbon silicon wafers $\quad 1619$

2.1. Classification of ribbon technologies 1619

2.2. The silicon ribbon growth mechanism, crystal structure, and machine
throughput

2.3. Refractory materials and impurities 1622

2.4. Examples of different ribbon technologies 1624

3. Defects 1626

3.1. Material properties 1626

4. Gettering 1630

4.1. Gettering techniques 1630

4.2. Gettering in EFG and SR materials 1631

4.3. Gettering in RGS material 1632

5. Hydrogen passivation $\quad 1632$

5.1. Interaction with defects 1633

5.2. Methods for hydrogen incorporation $\quad 1634$

5.3. Passivated defects and stability 1634

5.4. Hydrogenation of EFG and SR materials 1634

5.5. Hydrogenation in RGS material 1635

5.6. Diffusion of $\mathrm{H}$ in defected silicon 1636

6. Ribbon silicon solar cells 1638

6.1. Laboratory-type and industrial-type processing 1638

6.2. EFG and SR solar cells 1639

6.3. RGS solar cells 1641

6.4. Summary 1642

References $\quad 1644$

\section{Introduction}

In recent years the photovoltaic (PV) market has seen explosive growth with annual rates well above $30 \%$. In 2003, solar cell production exceeded $700 \mathrm{MWp}^{3}$ [1]. As more than $90 \%$ of all photovoltaic modules are silicon wafer based, this required more than 250 million wafers. The high market growth rate in combination with the need to substantially reduce solar electricity costs has resulted in a number of serious challenges for silicon wafer production development for photovoltaics. If today's trends can be extrapolated into the near future, we can expect that by 2010 the PV market will consume about 30.000 t of solar grade silicon to produce solar silicon wafers. This is more than the silicon semiconductor industry consumes today.

In order to meet these challenges, it is very likely that wafer manufacturing technology aimed at the photovoltaics market will continue to develop. The following requirements must be met:

- low silicon consumption (thinner wafers, reduction or elimination of wafer cutting losses),

- reduced investment requirements as regards crystal growth and wafer cutting equipment (high production speed, high machine up-time, inexpensive machines),

${ }^{3}$ Equivalent electrical power under standard test conditions. The typical cell output is $2.5 \mathrm{Wp}$; a photovoltaic module produces between 50 and $150 \mathrm{Wp}$. 
- increased wafer size (reduced processing per Wp),

- sufficient silicon quality to produce highly efficient solar cells.

Although the demand is very clear, the technological roadmap for meeting the above requirements is not clear. On one hand, existing technologies are continuously improved by means such as achieving faster growth of multicrystalline silicon ingots, producing larger ingots with more silicon in one crystallization step, and melt recharging in the case of Czochralski (Cz) crystal pulling. On the other hand, new, promising high speed silicon wafer manufacturing technologies are under development in order to meet the requirement of low silicon consumption in combination with high production speed.

In principle, the most promising wafer manufacturing technologies are the ones where liquid silicon is directly crystallized in the form of a silicon wafer or ribbon (so-called ribbon technologies). In order to enable a successful introduction of high speed ribbon silicon wafer technologies, however, the challenge is to reach sufficient wafer quality and solar cell efficiency to make a major contribution to future solar electricity cost reduction.

In the following, an overview of advanced ribbon silicon wafer manufacturing technologies for photovoltaics is given, with emphasis on silicon material properties in relation to the growth process and silicon material quality improvement by gettering and passivation procedures during wafer growth and solar cell processing.

Looking back into the history of photovoltaic silicon wafers, we find that early wafers originated from semiconductor silicon wafer processes (float zone or $\mathrm{Cz}$ ). Due to the pressure on manufacturing costs and the reduced demands for wafer characteristics such as surface morphology, contamination, and thickness variation, dedicated wafer manufacturing lines for the photovoltaic industry were established. This resulted in wafers that differ in many respects from a typical semiconductor wafer [2,3].

The technological basis for many of today's photovoltaic silicon ingot growth technologies as well as silicon ribbon technologies was developed in flat panel solar array projects [4]. Due to the very successful development of cost-efficient wafer cutting by multiwire sawing technologies, today's market is based on silicon ingot growth $(\mathrm{Cz}$ ingots, multicrystalline silicon ingots grown by SOPLIN [5], electromagnetic casting (EMC) [6], BridgmanStockbarger, and similar methods). A major drawback of silicon ingot casting and wafer cutting is the severe silicon loss due to kerf loss, rejection of tops, tails, and silicon parts that were in contact with the crucible. A silicon yield of less than $40 \%$ is typical for many of the silicon ingot growth technologies [7] and measures are taken in industry to reduce silicon losses in the ingot process. As wafer costs represent $40 \%-50 \%$ of the cost of a PV module, wafer manufacturing technologies with low costs and high silicon yield per solar electrical power output are an important milestone in the race to lower the cost of solar electricity.

In general, silicon wafer based solar energy technology follows a twofold strategy to reduce the costs of solar electricity. One approach is increasing the power output per area (i.e. conversion efficiency); the other is lowering manufacturing costs. As solar modules are area based devices with an energy conversion efficiency in the 15\%-16\% range and as the thermodynamic conversion limit for single-junction solar cells under terrestrial conditions is $31 \%$ [8], efficiency improvements have a cost reduction potential of at maximum $50 \%$, with $25 \%$ being more likely (record efficiencies for Si solar cells are in the $24 \%-25 \%$ range [9]). Hence efficiency improvement in itself is not sufficient to reach the demanding cost targets. The second and possibly larger cost reduction potential lies in reducing the manufacturing costs for not only wafer manufacturing but also all other steps throughout the production chain. If high speed, low cost processes for wafer manufacturing, solar cell processing, and module packaging can be developed, the module costs will approach the limit imposed by the 
materials in the solar module. In this respect, the application of a silicon ribbon technology with corresponding high silicon usage without compromising the conversion efficiency will be one step necessary to realize the ultimate silicon wafer based solar module.

\subsection{Electronic characteristics}

The most important electronic characteristics of a silicon wafer for use in a solar cell are the resistivity in the dark and the minority charge carrier lifetime. However, in contrast to the case for cast silicon wafers or $\mathrm{Cz}$ material, the as-grown characteristics of ribbon silicon material are slightly different. The resistivity of the wafer, which is determined by the type and amount of doping material that is added during crystal growth, is normally lower than for other wafers for solar applications. If boron doping is used, it turned out that the highest efficiency for ribbon silicon material is reached for $2-3 \Omega \mathrm{cm}$ material, while cast silicon material is typically doped with boron in the $0.5-2 \Omega \mathrm{cm}$ range.

The same is true for the minority carrier lifetime. Typical as-grown lifetimes for ribbon silicon are lower than those for cast and $\mathrm{Cz}$ doped wafers. Ribbon silicon wafers therefore depend upon solar cell processing steps for improving their electrical characteristics during the solar cell processing (gettering and passivation). Thus monitoring the minority carrier lifetime and diffusion length (respectively) throughout the solar cell processing has proven to be valuable in the development of ribbon materials.

The minority charge carrier lifetime, $\tau$, or, related to it via

$$
L_{\text {diff }}=\sqrt{ } D \tau,
$$

the minority charge carrier diffusion length, $L_{\mathrm{diff}}$, is a measure of the mean time or distance, respectively, that a charge carrier can travel before it is lost via a recombination process ( $D$ being the minority carrier diffusion constant). While there are different charge carrier recombination processes such as Auger recombination and recombination by emission of a photon possible in silicon, under typical operating conditions for a solar cell the most probable recombination mechanism is recombination via an energy level in the band gap. This is often referred to as Shockley-Read-Hall recombination [10,11]. The recombination rate, $R$, is strongly influenced by the energy level of the recombination centre, the capture cross section for electrons and holes, and the recombination centre concentration (see equation (2)); recombination centres can originate from crystallographic defects, impurities, or combinations of the two:

$$
R=\begin{gathered}
v_{\mathrm{th}} N_{t}\left(n p-n_{\mathrm{i}}^{2}\right) \\
{ }_{\sigma_{\mathrm{p}}}^{1}\left(n+n_{1}\right)+{ }_{\sigma_{\mathrm{n}}}^{1}\left(p+p_{1}\right)
\end{gathered} .
$$

$v_{\text {th }}$ is the thermal velocity, $N_{t}$ is the recombination centre density, $n(p)$ is the electron (hole) concentration, $n_{\mathrm{i}}$ is the intrinsic carrier concentration, $\sigma_{\mathrm{n}}\left(\sigma_{\mathrm{p}}\right)$ is the capture cross section for electrons (holes);

$$
\begin{aligned}
& n_{1}=n_{\mathrm{i}} \exp \left(\begin{array}{c}
E_{t}-E_{\mathrm{i}} \\
k T
\end{array}\right) \\
& p_{1}=n_{\mathrm{i}} \exp \left(\begin{array}{c}
E_{\mathrm{i}}-E_{t} \\
k T
\end{array}\right)
\end{aligned}
$$

with $E_{t}$ the energy of the recombination centre, $E_{\mathrm{i}}$ the intrinsic energy level.

The carrier lifetime, $\tau$, is related to the recombination rate by

$$
\tau=\begin{gathered}
\Delta n \\
R
\end{gathered}
$$

with $\Delta n$ being the excess carrier density. 


\subsection{Impurities}

Impurities are non-silicon atoms or clusters of atoms incorporated into the silicon crystal or wafer. One necessary impurity in the silicon wafer is the doping material. Other impurities originate from contamination during crystal growth, the silicon material used, or from handling of the silicon in the manufacturing process. The impurities with the highest concentrations in silicon wafers are typically oxygen and carbon. They can originate from silicon material $\left(\mathrm{SiO}_{2}, \mathrm{C}\right)$ in the case of low quality solar grade silicon or from refractory material (quartz or graphite crucibles) used during silicon processing. Typical concentrations of oxygen and carbon in silicon wafers used in photovoltaics are between $1 \times 10^{17}$ and $1 \times 10^{18} \mathrm{~cm}^{-3}$.

Other 'metallic' impurities are also found in photovoltaic wafers. Depending on the type of metal, even very low concentrations can have a negative influence on the minority carrier lifetime and solar cell efficiency $[12,13]$.

The behaviour of impurities in silicon and their influence on wafer quality and process technologies for impurity treatment (impurity gettering, passivation) constitutes a major topic in silicon research.

\section{Ribbon silicon wafers}

Driven by the motivation of increasing the Si yield in wafer manufacturing and avoiding the time- and energy-consuming and therefore costly steps of ingot growing and wafer cutting, research into and development of methods for crystallizing silicon directly in the planar form of a wafer have been going on for four decades [14-34] (see [35] for an early overview). It was only recently that some of the ribbon technologies reached maturity, and manufacture on a megawatt scale, such as in the cases of the edge-defined film-fed growth (EFG [36]) and the string ribbon (SR [37]) technologies, could emerge. Other technologies such as the silicon film [38], dendritic web [14], ribbon growth on substrate (RGS [30]) and rotational solidification techniques $[33,34]$ are under development at pilot demonstration phases.

\subsection{Classification of ribbon technologies}

To understand the potential of the different photovoltaic silicon ribbon technologies, a closer look at the wafer growth technology, wafer characteristics, and behaviour in the cell process is necessary.

In the past, the different ribbon Si technologies were classified in several ways:

(1) according to the shape of the meniscus built up at the liquid-solid interface (see figure 1);

(2) according to the transport direction of the solidified ribbon with respect to the movement of the liquid-solid interface during crystallization (type I: the liquid-solid interface moves in line with the ribbon transport direction (e.g., in EFG, SR methods); type II: the liquidsolid interface moves almost perpendicular to the ribbon transport direction (e.g., in the RGS method));

(3) according to the way in which the crystallization heat is removed (solidification heat is mainly removed by a contact with a 'cold' material, in type II, or by conduction through the solidified silicon wafer which is radiating in a colder environment, in type I);

(4) according to the seeding of the silicon crystals (either continuously seeding in the case of ribbons in contact with a cold substrate (type II) or by just initial seeding after which the crystal growth continues (type I)).

Obviously the circumstances during crystal growth have a major impact on the crystal structure and on the chemical, electrical, and mechanical properties of the silicon ribbon. 




Figure 1. Classification of silicon ribbon technologies according to the shape of the meniscus at the liquid-solid interface [35]. For M1 the lower part of the meniscus is formed by a shaping die, whereas M2 has a broad base at the free surface of the liquid. Both M1 and M2 represent ribbon techniques where the crystallization moves in the direction of ribbon transport (type I). M3 is characterized by a large liquid-solid interface and represents the techniques with wafer transport almost perpendicular to the crystal growth direction (type II).

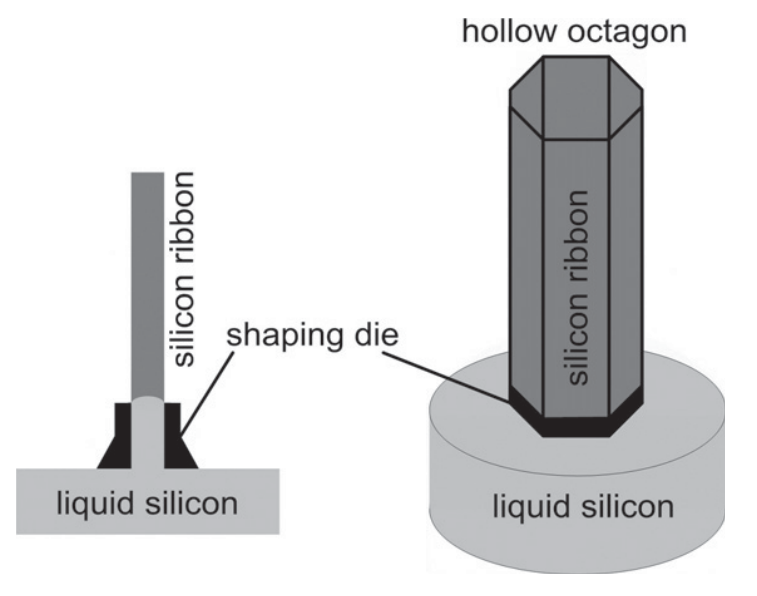

Figure 2. A schematic drawing of the edge-defined film-fed growth (EFG) technology as an example of a type I process. Liquid silicon is lifted by capillary forces through the die, where the silicon ribbon is pulled (left). Closed forms such as an octagon (side width 10 or $12.5 \mathrm{~cm}$ ) are used for the shape of the foil in order to avoid edge effects.

Silicon melt preparation, especially the dissolution of impurities from the crucible material, and the wafer cooling procedure are also crucial.

This will be demonstrated for three typical examples representing the most important silicon ribbon growth classes: the EFG (figure 2) and string ribbon processes where the crystallization interface moves in line with the ribbon transport direction; and the RGS material (figure 3) where the liquid-solid interface moves almost perpendicular to the ribbon transport direction.

\subsection{The silicon ribbon growth mechanism, crystal structure, and machine throughput}

In an ideal silicon ribbon growth technology, the wafer characteristics are completely determined by the way in which the crystallization heat (latent heat of fusion) is removed.

2.2.1. Type I. For type I technologies, the crystallization heat is transported by a temperature gradient from the liquid-solid interface through the solidified wafer to a colder area on the wafer, where heat is removed to the surroundings via radiation or other cooling mechanisms. In this type of process, the crystal growth speed is constant and is controlled by the heat flux through the wafer. In this case the maximum pulling velocity, $v_{\mathrm{p}}$ (growth rate), can be 


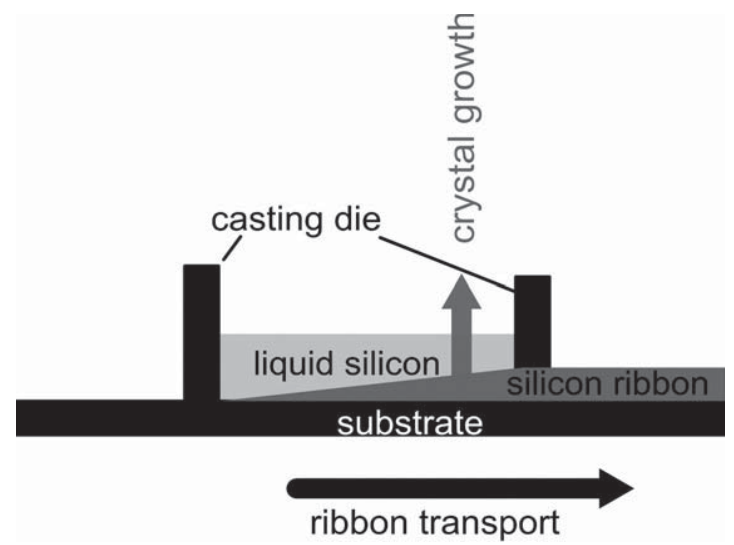

Figure 3. A schematic drawing of the ribbon growth on substrate (RGS) process, typical of type II technology. Preheated substrates are transported at the ribbon pulling speed underneath a casting frame filled with liquid silicon. The crystallization heat is removed into the 'cold' substrate and a 300-400 $\mu \mathrm{m}$ thick silicon film is grown. After the silicon ribbon is removed, the substrate is re-used in the process.

calculated as

$$
v_{\mathrm{p}}=1_{L \rho_{\mathrm{m}}}^{1}\left(\begin{array}{c}
\sigma \varepsilon(W+t) K_{\mathrm{m}} T_{\mathrm{m}}^{5} \\
W d
\end{array}\right)^{1 / 2}
$$

with $L$ being the latent heat of fusion, $\rho_{\mathrm{m}}$ the density of the crystal at the melting temperature, $\sigma$ the Stefan-Boltzmann constant, $\varepsilon$ the emissivity of the crystal, $K_{\mathrm{m}}$ the thermal conductivity of the solid crystal at the melting temperature $T_{\mathrm{m}}, W$ the ribbon width, and $d$ the ribbon thickness [39]. For $300 \mu \mathrm{m}$ thick ribbons, equation (4) predicts a maximum growth rate of $\sim 8 \mathrm{~cm} \mathrm{~min}^{-1}$.

Actual growth rates are much lower due to the maximum tolerable thermal stress limiting the maximum tolerable temperature gradient in the ribbon. The temperature gradient that is reached in the silicon ribbon is around $1000{ }^{\circ} \mathrm{C} \mathrm{cm}^{-1}$ close to the liquid-solid interface (for EFG [40]). This gradient causes stress, which increases with $\mathrm{d}^{2} T / \mathrm{d} y^{2}$ ( $y$ is the growth direction). The resulting dislocation formation and buckling are critical, limiting the realized growth speeds to $\sim 2 \mathrm{~cm} \mathrm{~min}^{-1}$ for plane ribbons of $\sim 300 \mu \mathrm{m}$ thickness, and to somewhat lower speeds for thinner ribbons (compared to the theoretical value of $\sim 8 \mathrm{~cm} \mathrm{~min}^{-1}$ ). The thermal environment around the newly formed ribbon above the crucible is crucial for the stress. Stacks of thermal shields and after-heaters are used to control and reduce stress [41]. The best approach is to confine stress as much as possible to the liquid-solid interface, where plastic flow can occur.

As the crystal growth is based upon the crystal structure of the already solidified silicon, the silicon ribbon exhibits long crystals in the ribbon growth direction with horizontal dimensions from the millimetre to centimetre range. Rapidly growing crystal orientations are preferred. Depending on the growth velocity and initial seeding, even monocrystalline material is possible [14].

2.2.2. Type II. In the case of type II silicon ribbons, the heat is removed from the liquid-solid interface through the solidified wafer into the cold substrate. Compared with the case for type I technologies, heat removal through the thin wafer with a large cross section is more effective, resulting in a much higher growth rate. 
In this case, the ribbon growth speed can be expressed as

$$
v_{\mathrm{p}}=\begin{gathered}
4 \alpha K_{\mathrm{m}} s \\
\left(2 K_{\mathrm{m}}-\alpha t\right) \mathrm{d} L \rho_{\mathrm{m}}
\end{gathered} \Delta T
$$

where $\alpha$ is the effective coefficient of heat transfer, $s$ the length of the liquid-solid interface (in the pulling direction), and $\Delta T$ the temperature gradient between the melt and the substrate [30]. For $\Delta T=160^{\circ} \mathrm{C}$, equation (5) predicts maximum growth rates of the order of $600 \mathrm{~cm} \mathrm{~min}{ }^{-1}$. This indicates that techniques with a large liquid-solid interface have the potential for very high pulling rates and therefore a higher throughput as compared to techniques of type I.

Due to the silicon crystal growth being in contact with the substrate, type II ribbons have completely different characteristics to type I ribbons. As crystal seeding takes place on the substrate, the wafers typically have small, columnar grains with random orientation. The crystal growth velocity is time dependent. The position of the liquid-solid interface follows a square-root dependence with faster initial crystal growth velocity when the liquid silicon is in direct contact with the substrate, and slower growth occurring with increasing thickness of the wafer due to the additional heat transport through the solidified silicon. The principle of the type II crystal growth can be described via the 'classical Stefan problem' [42]. This assumes that a liquid at uniform temperature $T_{1}$, which is higher than the melting temperature $T_{\mathrm{m}}$, is confined to a half-space $x>0$. At time $t=0$ the boundary surface $(x=0)$ is lowered to a temperature $T_{0}$ below the melting temperature (i.e. contact with the cold substrate) and maintained at this temperature. As a result, solidification starts at the surface $x=0$ and a liquid-solid interface $s(t)$ moves in the positive $x$-direction. Under these assumptions, the heat conduction equations can be solved and the position $s(t)$ of the liquid-solid interface as time varies is described by

$$
s(t)=\lambda \sqrt{ } \alpha_{\mathrm{s}} t
$$

where $\alpha_{\mathrm{s}}$ is the thermal diffusivity of the solid phase and $\lambda$ is the solution to the equation

$$
\begin{gathered}
\exp \left(\lambda^{2} / 4\right) \\
\operatorname{erf}(\lambda / 2)
\end{gathered}+\begin{gathered}
b T_{\mathrm{m}}-T_{1} \exp \left(-\lambda^{2} / 4 a\right) \\
\sqrt{ } a T_{\mathrm{m}}-T_{0} \operatorname{erfc}(\lambda / 2 \sqrt{ } a)
\end{gathered}-\begin{gathered}
\lambda \sqrt{ } \pi h_{\mathrm{sf}} \\
2 c_{\mathrm{ps}}\left(T_{\mathrm{m}}-T_{0}\right)
\end{gathered}=0
$$

with the following parameters: $b$ is the ratio of liquid to solid heat conductivity, $a$ is ratio of liquid to solid heat diffusivity, $L$ is latent heat of fusion, and $c_{\mathrm{ps}}$ is the specific heat capacity of the solid phase.

In general, crystal growth is more complex than that of the system outlined above due to the behaviour of $T_{0}$ (the temperature at the bottom of the solidified wafer), which in general is not constant, the temperature dependence of the material characteristics, and the often turbulent flow in the liquid silicon melt. The variable growth speed results in thickness dependent material characteristics due to processes such as velocity dependent effective segregation of metallic impurities.

In contrast to the case for type I crystal growth, where a relatively large temperature gradient in the solidified silicon is the driving force for crystallization, the temperature gradient through the solidified silicon in type II processes can be very small. Therefore, it is in principle possible to grow wafers with lower thermal stress, provided that other process parameters such as wafer cooling and other mechanical stresses are controlled.

\subsubsection{Comparison of growth techniques. See table 1.}

\subsection{Refractory materials and impurities}

In addition to the crystallization conditions, the materials that are used in ribbon growth equipment and the atmospheric environment are important factors influencing the wafer 
Table 1. Some data related to the crystal growth by SR and EFG (type I) and RGS (type II) methods.

$\begin{array}{lll} & \text { Type I } & \text { Type II } \\ \begin{array}{l}\text { Angle between crystal growth } \\ \text { direction and ribbon transport }\end{array} & 180^{\circ} & \text { Almost } 90^{\circ} \\ \begin{array}{l}\text { Typical ribbon growth } \\ \text { velocities }\end{array} & 1-2 \mathrm{~cm} \mathrm{~min}^{-1} & 600 \mathrm{~cm} \mathrm{~min}^{-1} \\ \begin{array}{l}\text { Typical annual wafer output } \\ \text { Crystallization velocity }\end{array} & \sim 0.5 \text { mill. wafer/machine } & \sim 20 \text { mill. wafer/machine } \\ \text { Crystal size } & \text { Constant }\left(1-2 \mathrm{~cm} \mathrm{~min}{ }^{-1}\right) & \text { Variable (mean } 2 \mathrm{~cm} \mathrm{~min}^{-1} \text { ) } \\ & \begin{array}{l}\text { Extended crystals in pulling } \\ \text { directions, mm to cm } \\ \text { dimensions perpendicular } \\ \text { to pulling direction }\end{array} & 100 \mu \mathrm{m} \text { to } 1 \mathrm{~mm} \text { range } \\ & \begin{array}{l}\text { EFG: close to }\{011\}[43,44] \\ \text { High (tolerable thermal stress }\end{array} & \text { Random } \\ \text { Thermal stress } & \text { limits growth velocity) } & \text { Low } \\ & \end{array}$

characteristics. In most ribbon technologies the solidification area is in close proximity to the refractory materials (such as the shaping die for EFG or the casting frame and substrate for RGS). In contrast to the case for ingot casting, it is not possible to discard the silicon that was crystallized in contact with the refractory material. In addition, other technologies such as $\mathrm{SiO}$ evaporation in the $\mathrm{Cz}$ process are not possible due to the close proximity of the crystallization process to refractory material. Therefore, much research has gone into the development of silicon resistant refractory materials with the aim of minimizing the resulting contamination [45]. The result was the finding that most ceramic materials produced in combination with metal oxide binders cannot be used due to the very low contamination tolerance of silicon wafers to metallic impurities $[12,13]$. The same is true for ceramics including doping elements such as B (in BN) or Al (in SiAlON). Today, only quartz [46] and graphite based crucibles [47] are in common use as refractory materials. Most ribbon growth technologies rely on graphite components due to the mechanical and thermal properties of the material, the good availability of semiconductor grade material, and the relatively high tolerance of silicon to graphite contamination. Understanding the dissolution reaction and solubility limits of refractory materials and impurities therein has been crucial in the development of silicon ribbons and is needed to understand the characteristics of the material.

The behaviour of quartz crucibles and the interaction with liquid silicon were examined thoroughly with a view to controlling the oxygen content in $\mathrm{Cz}$ wafers [48]. The important interaction of liquid silicon with graphite crucibles and the formation of a $\mathrm{SiC}$ interface layer constitute a topic of ongoing research that is important for the further development of silicon ribbons. It is generally assumed that the initial contact of pure liquid silicon with graphite leads to the dissolution of graphite in the silicon [49]. From reactive wetting experiments there are indications that this dissolution of graphite is a very rapid process, as is the diffusion of carbon in liquid silicon [50,51]. Normally, this behaviour should result in a carbon saturated silicon melt, but scanning electron microscopy analyses of the silicon-graphite interface show the existence of a $\mathrm{SiC}$ layer at the interface [52]. The growth of the $\mathrm{SiC}$ layer takes place in two different growth regimes: in the initial one with the linear kinetics of an interface reaction limited process, followed by a slower process with approximately parabolic kinetics, which can be explained by a growth process that is limited by carbon diffusion through the $\mathrm{SiC}$ layer. 
Therefore, after the initial growth of the $\mathrm{SiC}$ interface layer, the further dissolution of carbon from the graphite crucible is kinetically hindered by diffusion through a $\mathrm{SiC}$ interface layer.

Of high technological interest is the carbon concentration in the wafers in relation to the growth conditions. Experiments [53] show that the solubility of carbon in liquid silicon equilibrated with $\mathrm{SiC}$ can be described by

$$
\log \left(\begin{array}{c}
{[\mathrm{C}]} \\
\operatorname{mass} \%
\end{array}\right)=3.63-\begin{gathered}
9660 \\
T
\end{gathered} \quad \text { for } T: 1723-1873 \mathrm{~K} .
$$

At the silicon melting point, this should result in carbon concentrations of $9.1 \times 10^{18} \mathrm{~cm}^{-3}$. As the carbon solubility in solid silicon is $3.5 \times 10^{17} \mathrm{~cm}^{-3}$ at the melting point of Si, the high carbon solubility in the liquid silicon should result in carbon supersaturated solidified silicon or the formation of $\mathrm{SiC}$ either residually in the melt or incorporated in the silicon crystal.

Despite the high level of dissolution of carbon in liquid silicon, it is technically possible to produce silicon ribbons with substitutional carbon concentrations lower than $1 \times 10^{18} \mathrm{~cm}^{-3}$ or even in the $5 \times 10^{17} \mathrm{~cm}^{-3}$ region in a graphite environment [47]. As carbon contamination is important for the electrical and mechanical properties of the silicon wafer, the growth of silicon ribbons with carbon content well below the liquid solubility is very much desired.

\subsection{Examples of different ribbon technologies}

In the following we will focus on the silicon ribbon technologies that were most widely studied in the past. The edge-defined film-fed growth and string ribbon methods were chosen as typical representatives of type I silicon ribbon technologies and ribbon growth on substrate as the type II technology.

2.4.1. Edge-defined film-fed growth (type I technology). In the EFG process commercialized at Mobil Tyco and ASE (now RWE Solar), the silicon ribbon is pulled to heights of up to $7 \mathrm{~m}$ from the top of a graphite die (shape of meniscus: M1) through which molten silicon is fed by capillary action. Extensive temperature control by radiation shields, cold shoes, and after-heating realizes a maximum temperature gradient where plastic flow is possible, in order to allow for a maximum growth rate as described above $[54,55]$.

The silicon is contained in a graphite crucible, which contains only about $1 \mathrm{~kg}$ of silicon. It is continuously replenished, with up to $200 \mathrm{~kg}$ Si supplied during a growth run. The solid silicon ribbon is (super)saturated with carbon but contains very little oxygen. Crystal grain dimensions are typically of the order of a few $\mathrm{mm}$ in width but can reach great lengths in the crystal growth direction. The as-grown diffusion length is related to the purity of the graphite parts. The tubes (octagons) are cut into wafers $\left(10 \times 10,10 \times 15\right.$, or $\left.12.5 \times 12.5 \mathrm{~cm}^{2}\right)$ by a laser.

2.4.2. The string ribbon process (type I). The string ribbon technology (figure 4) was invented at the National Renewable Energy Laboratory and at Arthur D Little, commercialized by Evergreen Solar Inc. It uses high temperature resistant strings, which are drawn at a distance of $8 \mathrm{~cm}$ through a crucible with liquid silicon. They pull up a Si meniscus (M2) of about $7 \mathrm{~mm}$ height, which crystallizes to become the ribbon. In comparison to the case for the EFG technique (where temperature near the liquid-solid interface must be controlled to $\pm 1 \mathrm{~K}$ ), temperature control near the liquid-solid interface is less critical $( \pm 10 \mathrm{~K}$ is tolerated $)$ and this allows the use of more cost-effective furnace designs [37].

The result is a silicon ribbon with a typical dislocation density of less than $10^{5} \mathrm{~cm}^{-2}$. The main defects in the central area of the ribbon are twins, and at the edges high angle 


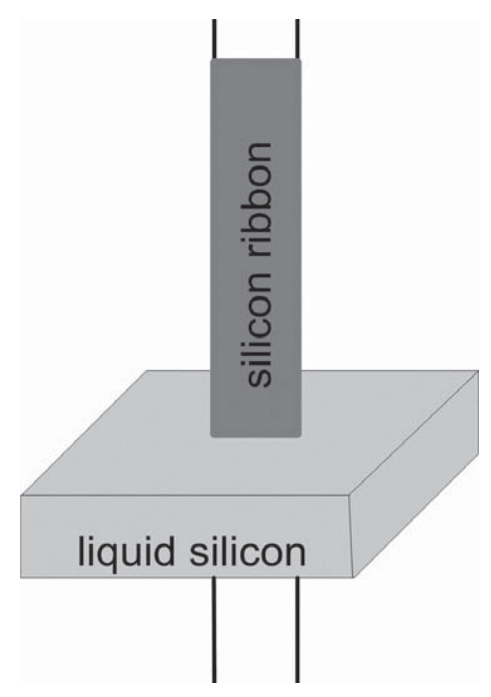

Figure 4. A schematic drawing of the string ribbon (SR) process. Two strings are pulled through the silicon melt. They define the edges of the silicon film.

grain boundaries occur due to heterogeneous nucleation. The typical grain size for $300 \mu \mathrm{m}$ thick ribbons is around $1 \mathrm{~cm}$ or even larger for thinner ribbons. As with EFG, the oxygen concentration is low, but the carbon concentration is reduced.

Like in the EFG case, an after-heater construction around the crystallization area is used to reduce thermal stress [41]. As for EFG material production, the string ribbon technology uses a small silicon melt crucible in combination with continuous melt replenishment. To help overcome the problem of limited throughput of only one ribbon per furnace, compared to eight ribbons in the octagon for EFG, two ribbons [56] (and even four with a recently published new crucible design [57]) can be grown simultaneously in one furnace. The ribbon is cut into $8 \times 15 \mathrm{~cm}^{2}$ wafers.

2.4.3. Ribbon growth on substrate (type II). The principle of the ribbon growth on substrate (RGS) process is that a series of graphite based substrates move at high velocity (typically $10 \mathrm{~cm} \mathrm{~s}^{-1}$ or $6 \mathrm{~m} \mathrm{~min}^{-1}$ ) under a casting frame, which contains liquid silicon, and defines the size of the wafers and the solidification front.

The crystal growth speed can be controlled by the heat extraction capacity of the substrate material. During cooling, the difference in thermal expansion coefficient between the substrate material and Si ribbon causes a separation of the silicon ribbon from the substrate and allows the re-use of the substrate material.

In the former laboratory scale wafer manufacturing process, RGS wafers were characterized by an extremely high oxygen content of $2-4 \times 10^{18} \mathrm{~cm}^{-3}$, which limited the solar cell efficiency [58]. Unless the wafers are quenched to room temperature in a few seconds after solidification, the oxygen will mostly ( $>90 \%)$ precipitate (e.g. as recombination active new donors formed at $600-900^{\circ} \mathrm{C}$ or, when cooling more slowly, as larger precipitates [59]). This precipitation is enhanced by the high carbon content. There have been two approaches for producing RGS wafers that could be used in a solar cell process. The first of these was production of quench-cooled wafers, which have a high interstitial oxygen content and therefore have to be processed avoiding new donor formation, which takes place at temperatures between 
600 and $900{ }^{\circ} \mathrm{C}$. Such wafers are not suited for 'standard' solar cell processes. The other approach was precipitating the oxygen in the form of large clusters via a high temperature treatment. In this case, the wafers could be processed in a temperature range between 600 and $900^{\circ} \mathrm{C}$ and standard cell processing could be applied. The drawback of the latter method is a prolonged annealing step at temperatures $>1000^{\circ} \mathrm{C}$ directly after crystallization which was not practicable in the planned industrial-type wafer fabrication.

Just recently, it has been found that the high oxygen content can be significantly reduced to values of $5-7 \times 10^{17} \mathrm{~cm}^{-3}$ by changing the crucible design (replacing quartz components by graphite parts). This reduction has resulted in a material quality allowing standard solar cell processing temperature cycles with RGS wafers rapidly cooled after crystallization [58].

The RGS method was developed by Bayer AG in the 1990s. It is now under development in a cooperation between Deutsche Solar AG and a consortium of the Energy Research Centre of the Netherlands and Sunergy.

\section{Defects}

As nearly all of the ribbon silicon growth techniques developed result in multicrystalline material, crystal defects play a major role in the solar cell efficiencies obtained for ribbon silicon wafers. There is a general trend for higher defect concentrations with faster ribbon growth, but even within wafers obtained by one growth technique there is an inhomogeneous defect distribution. In this section, we will subject the known relevant defects for the three types of material (produced by EFG, SR, and RGS processes) to closer examination. Interaction between different types of defect must be taken into account and for one example we will discuss the possibility of making use of certain kinds of defects to improve solar cell efficiency.

\subsection{Material properties}

The specific growth conditions for the silicon ribbons result in the material properties listed in table 2. EFG and SR materials both have grains elongated in the growth direction in the centimetre range with a tendency towards larger grains for SR material. Twinning occurs frequently within the grains, but does not necessarily reduce the carrier lifetime or diffusion length, $L_{\text {diff }}$. The ribbon thickness for all technologies is $\sim 300 \mu \mathrm{m}$, and therefore comparable with that of standard ingot cast wafers. The resistivities due to boron doping are slightly higher than for ingot cast wafers, and are in the $2-4 \Omega \mathrm{cm}$ range. The higher optimum resistivity than used for standard ingot cast multicrystalline wafers $(\sim 1 \Omega \mathrm{cm})$ may be related to the high carbon concentration. A possible recombination centre involving both boron and carbon might be responsible for the observed material degradation detected for lower resistivity material [60], although the underlying defect has not yet been identified.

EFG and RGS materials share very high carbon concentrations due to the contact with graphite-containing materials near the liquid-solid interface (die or substrate). The oxygen concentration is very low for EFG and SR materials, and high for RGS material. The grain size is smaller for RGS material $(0.1-0.5 \mathrm{~mm})$ as there are more nucleation sites on the substrate. The dislocation density in RGS material generally tends to be higher than those for EFG and SR materials, which means that the possibility of stress free wafer growth is not yet fully realized.

Additionally, transition metals are present in all materials, although mostly in concentrations not limiting material quality. Nevertheless, some are effective recombination centres such as point defects or in the form of precipitates, and affect the as-grown material quality. 
Table 2. Properties of materials produced by the three ribbon techniques under close consideration.

$\begin{array}{llllllll}\text { Material } & \begin{array}{l}\text { Grain } \\ \text { size }\end{array} & \begin{array}{l}\text { Dislocation } \\ \text { density }\left(\mathrm{cm}^{-2}\right)\end{array} & \begin{array}{l}\text { Thickness } \\ (\mu \mathrm{m})\end{array} & \begin{array}{l}\text { Resistivity } \\ (\Omega \mathrm{cm})\end{array} & \begin{array}{l}{[\mathrm{C}]} \\ \left(\mathrm{cm}^{-3}\right)\end{array} & \begin{array}{l}{[\mathrm{O}]} \\ \left(\mathrm{cm}^{-3}\right)\end{array} & \begin{array}{l}\text { As-grown } \\ L_{\text {diff }}(\mu \mathrm{m})\end{array} \\ \text { EFG } & \mathrm{cm} & 10^{4}-10^{5} & 300 & 2-4 & 10^{18} & <5 \times 10^{16} & 10-300 \\ \text { SR } & \mathrm{cm} & 10^{4}-10^{5} & 300 & 3 & 5 \times 10^{17} & <5 \times 10^{16} & 10-300 \\ \text { RGS } & <\mathrm{mm} & 10^{5}-10^{7} & 300 & 2 & 10^{18} & 10^{18} & \sim 10\end{array}$

The effects of an isolated defect on material quality (e.g. recombination activity of a clean, undecorated dislocation, capture cross sections of point defects) are well known for many defects present in crystalline silicon material, but the interactions of the impurities or structural defects form a major challenge in obtaining an improved understanding of the complex situation in the solidified silicon ribbon. In the following sections, some of these interactions are addressed. As EFG and SR materials are very similar, they will be dealt with in the same section, although most of the results have been obtained for EFG material.

\subsubsection{EFG and SR materials.}

Stress and dislocations. Ribbon technologies with the plane of the liquid-solid interface perpendicular to the growth direction all suffer from built-in stress due to the varying thermal gradient in the solidified ribbon [61]. This stress can lead to the formation of areas with high dislocation density. In these areas carrier lifetimes are reduced as shown by photoluminescence spectroscopy $[62,63]$ and transmission electron microscopy (TEM). High stresses can be detected also in areas with a low dislocation density [64]. Areas only containing twins without increased dislocation densities do not show reduced lifetimes. They are, however, highly stressed and there is evidence that this might be due to incorporation of carbon into the twin boundaries [65].

It is known that clean dislocations without decoration reveal almost no recombination activity [66] but increasing decoration with impurities leads to recombination centres deep in the band gap which significantly reduce the carrier lifetime [67]. It can therefore be concluded that the most detrimental defects in EFG and SR materials apart from recombination active large angle grain boundaries are decorated dislocations.

Microdefects. Other types of defects are also present in EFG and SR materials. The $V / G$ ratio of EFG and SR materials (with $V$ being the growth speed and $G$ the liquid-solid interface temperature gradient) is comparable to that of the microdefect regime of $\mathrm{D}$ swirls in float zone growth [60]. Kalejs assumes that due to the high $[\mathrm{C}] /[\mathrm{O}]$ ratio compared to those of other multicrystalline materials, a certain microdefect regime during cooling is achieved. It is at present unclear whether these microdefects contain carbon, but taking into account the high carbon content, this seems quite probable [60]. This assumption is supported by the observation that the precipitation of Fe is greatly enhanced in EFG material compared to other crystalline silicon materials [68]. It is known that high densities of structural defects (e.g., oxygen precipitates and dislocations) increase the rate of Fe precipitation, but the enhanced rate of precipitation in EFG was observed even in large grained areas with low dislocation density. This is a strong indication that microdefects are present in the material after crystallization [69].

Carbon, $S i_{I}$, and $S i_{V}$. The concentration of silicon self-interstitials $\left(\mathrm{Si}_{\mathrm{I}}\right)$ and vacancies $\left(\mathrm{Si}_{\mathrm{V}}\right)$ is another important characteristic of silicon ribbons. The appearance of $\mathrm{Si}_{\mathrm{V}}$-rich D defects 
with increasing $V / G$ ratio in room temperature EFG shows that $\mathrm{Si}_{\mathrm{I}}$, which are the dominant point defects at temperatures greater than $1000^{\circ} \mathrm{C}$, vanish during cooling down [60]. The high $\mathrm{Si}_{\mathrm{V}}$ concentration together with the low oxygen concentration (table 3 ) has a severe impact on carbon precipitation. Although the carbon concentration in EFG is above the equilibrium saturation value of $3.5 \times 10^{17} \mathrm{~cm}^{-3}$, the precipitation of carbon is almost negligible for temperatures up to $1000{ }^{\circ} \mathrm{C}$ and annealing times as long as $72 \mathrm{~h} \mathrm{[70].} \mathrm{This} \mathrm{is} \mathrm{in} \mathrm{strong} \mathrm{contrast}$ to the case for oxygen-rich materials where carbon precipitation is detectable at temperatures of $>500^{\circ} \mathrm{C}$. The carbon precipitation is normally triggered by a high $\mathrm{Si}_{\mathrm{I}}$ concentration, which enhances carbon diffusion via a kick-out mechanism [71]. On the other hand, the concentration of $\mathrm{Si}_{\text {I }}$ itself can be increased by the precipitation of oxygen. The reduced carbon precipitation rate in $\mathrm{EFG}$ can therefore be attributed to the combination of low oxygen and low $\mathrm{Si}_{\mathrm{I}}$ contents.

Transition metals. Transition metals are known to be recombination centres in crystalline silicon. Studies on deliberately contaminated EFG wafers have shown the detrimental impact of different metals such as $\mathrm{Cr}$, Mo, V, Ti, and Fe [72, 73]. As Ti, V, and Mo are slowly diffusing in silicon, they cannot be effectively gettered in the solar cell process (see the section on gettering). It can also be shown that $\mathrm{Fe}$ and $\mathrm{Cr}$ pair with the boron acceptor. The formation of the $\mathrm{Cr}-\mathrm{B}$ pair always results in a decrease in lifetime and pairing can be revoked by a $200{ }^{\circ} \mathrm{C}$ anneal $[74,75]$. On the other hand, the harmfulness of $\mathrm{Fe}-\mathrm{B}$ pairing as compared to interstitial $\mathrm{Fe}\left(\mathrm{Fe}_{\mathrm{I}}\right)$ depends on the injection level. At low injection levels, $\mathrm{Fe}_{\mathrm{I}}$ leads to lower lifetimes than $\mathrm{Fe}-\mathrm{B}$ pairs, whereas for high injection levels, $\mathrm{Fe}-\mathrm{B}$ pairs show a higher recombination activity than $\mathrm{Fe}_{\mathrm{I}}$ [76]. The detrimental effect of both impurities, $\mathrm{Fe}$ and $\mathrm{Cr}$, is strongly dependent on the B dopant concentration [74, 76] and might explain the need for the use of higher resistivity material for producing silicon ribbons in comparison with standard cast multicrystalline wafers. As Fe and $\mathrm{Cr}$ in isolated form diffuse fast, these elements can be gettered more easily, which is essential for improving material quality during solar cell processing.

\subsubsection{RGS material}

Oxygen. Apart from a larger amount of grain boundaries due to the smaller grain size in RGS material, there are other defects affecting the as-grown material quality of this high speed ribbon production technique. Older material (from before 2003) was characterized by high carbon concentrations combined with a high oxygen content. The main source of the carbon is graphite components in contact with molten silicon (e.g., substrate) whereas the oxygen is introduced via quartz components of the crucible and the process atmosphere. The high oxygen concentration, in the form of interstitials, was responsible for the formation of lifetime reducing defects: in addition to the formation of thermal donors at temperatures of $<600^{\circ} \mathrm{C}, \mathrm{SiO}_{x}$-containing new donors are formed in the temperature range $600-900^{\circ} \mathrm{C}$ when high interstitial oxygen levels are present [77]. This formation is enhanced by a high carbon concentration [78] and can drastically reduce carrier lifetimes in RGS material [79]. Oxygen-rich material was therefore annealed at temperatures of $>1000^{\circ} \mathrm{C}$ directly after crystallization to reduce the interstitial oxygen concentration via the formation of large precipitates (amorphous $\mathrm{SiO}_{2}$ [59, 80]; figure 5). Recent changes in crucible design led to lower oxygen concentrations comparable with those of multicrystalline wafers from cast ingots. Annealing steps to achieve a deliberate oxygen precipitation to avoid new donor formation are therefore no longer necessary [58].

Carbon. The high carbon concentration in combination with the high oxygen content led to precipitation features in RGS material that could be detected by etching experiments [81]. 


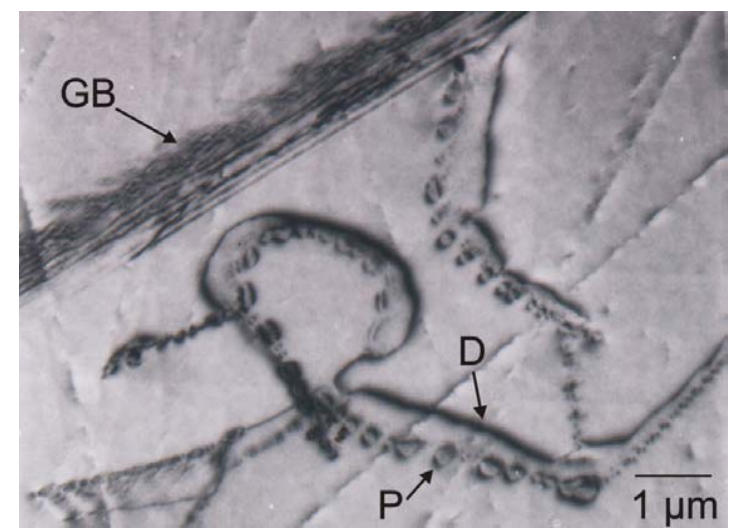

Figure 5. TEM investigation of an oxygen-rich RGS wafer. In addition to dislocations (D) and a grain boundary $(\mathrm{GB})$, the strain fields of precipitates $(\mathrm{P})$ are visible; these are strung together along the dislocations. As the dislocation line moved at high temperatures, the dislocation again provided nucleation sites for a new line of (now smaller) precipitates.

Filament-type structures could be visualized and their elemental composition was determined by TEM and energy dispersive x-ray analysis to consist of both carbon and oxygen. The formation of $\mathrm{C}$ precipitates after annealing steps for RGS materials differing in oxygen content has been studied as well [82]. The shape of the precipitates formed is disc-like with a high axial ratio for low oxygen samples annealed at high temperatures $\left(1020^{\circ} \mathrm{C}\right)$, whereas annealing at lower temperatures $\left(920^{\circ} \mathrm{C}\right)$ leads to a larger number of smaller disc-like precipitates independently of the oxygen content.

Metals. Metals have been detected in RGS wafers using synchrotron based x-ray fluorescence [83] in areas of low material quality. This contamination was believed to originate from the laboratory-type RGS production machine and led to modifications which resulted in a reduction in the content of metal impurities. Nevertheless, metals could still play a role in lifetime reduction for current RGS material quality, as some parts of the laboratory-type fabrication machine cannot be rebuilt at the moment. It is believed that for wafers from a continuously operating machine currently under construction, metal contamination will be reduced further.

Metal precipitation is enhanced at extended defects, as could be detected by means of $\mathrm{x}$-ray fluorescence with enhanced spatially resolved measurements of $\sim 1 \mu \mathrm{m}$ [84].

Carrier mobility. The increased defect density in RGS material influences material quality in several ways. Most defects decrease minority carrier lifetimes because of their recombination activity, but the mobility of charge carriers can also be affected. Majority charge carrier mobility can be determined by Hall measurements. More interesting for solar cell applications are the mobilities of minority charge carriers. These can be calculated for materials with diffusion lengths smaller than the wafer thickness by making use of equation (1) [85]. Minority carrier mobilities are reduced for oxygen-rich RGS material by a factor of 2-3 compared to those of monocrystalline material [85]. This increased scattering reduces the carrier diffusion constant and must be taken into account for device simulations. To a lesser extent, this holds true for all crystalline silicon materials where defects significantly affect material quality, but is usually neglected. 
Carrier collecting channels. Although crystal defects increase recombination strength and therefore reduce $L_{\text {diff }}$, in RGS material there is the possibility of making use of them and increasing the short circuit current density $J_{\mathrm{sc}}$ of a solar cell. Extremely high $J_{\mathrm{sc}}$ values have been observed in RGS solar cells; this can be explained by local inversion of the p-type base material [80]. Although lifetimes have been below $1 \mu \mathrm{s}$, a $J_{\mathrm{sc}}>34 \mathrm{~mA} \mathrm{~cm}^{-2}$ could be reached [86]. The enhanced collection probability could be explained by a three-dimensional extension of the surface emitter by a network of dislocations pervading the whole bulk of the wafer [87]. Closely packed precipitates containing oxygen and most probably carbon could be found along dislocation lines [86]. If a fixed positive charge at the surface of the oxygencontaining precipitates exists, then a repulsion of majority carriers (holes) can cause inversion around the precipitates. If the precipitates and the space charge regions formed around them overlap and are in contact with the diffused emitter at the wafer surface, extension of the emitter into the bulk reduces the distance that carriers have to diffuse to be collected. This mechanism can be very effective, provided that the average distance between the dislocations of the carrier collecting network is smaller than $L_{\text {diff }}$, as is the case in RGS material. Unfortunately, although $J_{\text {sc }}$ can be substantially improved, the increased space charge region and shunting problems cause reductions in fill factor and $V_{\text {oc }}$ (open circuit voltage). Therefore, to date, conversion efficiencies could not be significantly increased by making use of these carrier collecting channels [86].

\section{Gettering}

Progress in state-of-the-art solar cell processing has allowed the use of highly defected crystalline silicon wafers in industrial production without a major reduction in cell efficiency. One prerequisite for obtaining acceptable efficiencies is that material quality is improved during cell processing. This can be achieved by gettering (this section) and hydrogenation steps (next section). A typical state-of-the-art industrial-type cell process for multicrystalline silicon material includes the steps shown in figure 10: formation of the emitter by in-diffusion of $\mathrm{P}$ at temperatures between 800 and $900^{\circ} \mathrm{C}$ for about $\sim 20 \mathrm{~min}$, deposition of a $\mathrm{SiN}_{x}$ antireflection coating (ARC), and thick film metallization at the front (Ag) and rear sides (Al), followed by a firing step $\left(700-850^{\circ} \mathrm{C},<1 \mathrm{~min}\right.$ ) for $\mathrm{BSF}$ (back surface field) and contact formation. The challenge in processing defected, as-grown silicon ribbon wafers into highly efficient solar cells is to use lifetime improving steps within the cell process to achieve a significant increase in material quality.

\subsection{Gettering techniques}

Gettering techniques are well established tools for improving material quality by removing metals from the active area of a crystalline silicon based device [88]. Impurities can be gettered either within the bulk of the wafer (internal gettering, e.g. at oxygen precipitates [89]), or near the wafer surface (external gettering). In contrast to the case for wafers for integrated circuits, for solar cells the whole silicon bulk represents the active area of the device. Therefore, removing impurities by external gettering can improve bulk material quality in solar cell processing. The gettering process involves three steps: the first step is the release of the defect (metal atom) from its associated form, the second is the diffusion to the gettering region, and the third step is the capture of the impurity at the gettering site [90]. Elevated temperatures are necessary to release the impurities and to enhance their diffusion in silicon. On the other hand, the captured impurities should not be released from the gettering site. These two constraints mean that gettering sequences in principle should be material and impurity specific [91]. 
To keep costs for solar cell production as low as possible, gettering steps should already be part of the cell process. Two standard process steps have the potential to improve material quality in industrial-type solar cell processing.

$P$ gettering. For emitter formation by in-diffusion of phosphor a $\mathrm{P}$-containing $\mathrm{SiO}_{2}$ layer $(\mathrm{P}$ glass) is grown on the wafer surface at temperatures between 800 and $900{ }^{\circ} \mathrm{C}$. During $\mathrm{SiO}_{2}$ growth, $\mathrm{Si}_{\mathrm{I}}$ are injected from the $\mathrm{Si}-\mathrm{SiO}_{2}$ interface into the bulk. These interstitials can remove metals from substitutional lattice sites to interstitial ones via a 'kick-out' reaction [92]. The mobile metal atoms can then be captured at gettering sites near the wafer surface (e.g., SiP particles [93]), and the resulting diffusion gradient causes an effective reduction of metals in the silicon bulk (injection induced gettering).

Al gettering. The second fabrication step suited to gettering action during standard solar cell processing is the metallization of the rear side with aluminium. During BSF formation at temperatures above the eutectic point of $\mathrm{Al} / \mathrm{Si}\left(577^{\circ} \mathrm{C}\right)$, the solubility of most metals is a factor of $\sim 10^{4}$ higher in the eutectic than in the silicon bulk [94]. Gettering action here is again driven by the diffusion gradient towards the Al coated surface (segregation induced gettering).

A combination of the two gettering techniques (P/Al cogettering) can lead to even better results [95-97].

Fast diffusing dissolved metals such as $\mathrm{Cu}, \mathrm{Ni}, \mathrm{Co}, \mathrm{Au}, \mathrm{Fe}$, and $\mathrm{Cr}$ can be gettered effectively because their diffusion constants allow the penetration of the whole wafer within minutes at temperatures of $850^{\circ} \mathrm{C}$ [98]. In contrast, elements such as Ti, V, and Mo diffuse more slowly, so they can hardly be gettered at all for times and temperatures relevant for solar cell processing $[60,99]$.

\subsection{Gettering in EFG and SR materials}

Gettering in ribbon silicon materials is different to that in monocrystalline silicon because of the complex interaction between metals and other defects. For example, Fe can form precipitates at extended defects that are quite stable and cannot be dissolved easily during the gettering step [68]. Detailed gettering studies based on lifetime measurements have been reported for EFG [100-103] and SR materials [104, 105]. One main difference between the studies is in the measurement technique used for the determination of lifetimes. Whereas QSSPC (quasi-steady-state photoconductance) averages over several $\mathrm{cm}^{2}$ and therefore gives only integral values $[100,101,104]$, the microwave-detected photoconductance decay $(\mu \mathrm{PCD})$ method has a spatial resolution of $<1 \mathrm{~mm}$ and can distinguish between regions of different material quality within the mappings obtained [102, 103, 105]. The drawback of the latter is the more complicated procedure for obtaining an accurate determination of lifetimes $[103,106]$. Gettering studies using a CO flux during crystallization of EFG ribbons have also been carried out [107]. The observed gettering effect for $\mathrm{Cr}$ and $\mathrm{V}$ impurities deliberately added into the melt is ascribed to SiC-like complexes formed in the near-surface region.

Results obtained for EFG and SR materials are comparable on a qualitative scale. The lifetime enhancement is slightly more pronounced for $\mathrm{Al}$ gettering than for $\mathrm{P}$ gettering $[60,101,102,104]$. This could be explained by the high $\mathrm{Si}_{\mathrm{V}}$ (low $\mathrm{Si}_{\mathrm{I}}$ ) concentration present in EFG and SR materials (see the section on defects or table 3), because a high $\mathrm{Si}_{\mathrm{I}}$ flux is necessary for the kick-out reaction in injection induced $\mathrm{P}$ gettering.

$\mathrm{Al}$ gettering experiments were performed at $800^{\circ} \mathrm{C}$ for $30 \mathrm{~min}[102,103,105]$ or $850{ }^{\circ} \mathrm{C}$ for $2 \mathrm{~min}[101,104]$. During standard industrial-type contact firing, gettering times are much shorter $(<1 \mathrm{~min})$ and in the temperature range of $700-850^{\circ} \mathrm{C}$. It has been shown that the 
shorter gettering step normally used for industrial solar cell production produces inferior results compared to the prolonged Al gettering step [108]. This can be simply explained on the basis of the time needed for diffusion of atoms at a given temperature to reach the gettering site. A longer $\mathrm{Al}$ gettering step in industrial fabrication of solar cells cannot be performed without constrictions, as the firing step applied is also necessary for hydrogenation (see the next section) and metal contact formation.

Determination of spatially resolved lifetimes opens the possibility for tracking areas of good and low as-grown quality separately. Areas of good as-grown quality show a larger increase in lifetime compared to regions of low as-grown quality for both $\mathrm{Al}$ and $\mathrm{P}$ gettering [102, 105]. A possible explanation is that in poor lifetime regions with high dislocation density, metals are present in the form of precipitates (e.g., at extended defects such as dislocations [68]), which cannot be dissolved easily during gettering. In good quality areas, metals might be present either dissolved, or in the form of precipitates that can be easily dissolved at high temperatures and subsequently gettered. One example is provided by the presence of iron precipitates in the form of iron silicate (almost non-dissolvable) or iron silicide (dissolvable) [83].

Spatially resolved lifetime measurements additionally allow the determination of standard deviations [103]. These values are very high due to the inhomogeneity of the material. They give a hint as to the amount of information that is lost when performing integral measurements and again reveal the need for spatially resolved measurement techniques for an accurate characterization of ribbon material of inhomogeneous quality (figure 7).

\subsection{Gettering in RGS material}

The beneficial effect of gettering steps for the formerly oxygen-rich RGS material is limited by internal gettering processes at oxygen-containing precipitates [109]. This undesired gettering effect does not remove the metals completely out of the active area (the bulk of the wafer), but can lead to an increased recombination strength of precipitates located at extended defects (e.g., dislocations). In figure 6, mapped lifetimes for an oxygen-rich RGS wafer $\left([\mathrm{O}]=3 \times 10^{18} \mathrm{~cm}^{-3}\right)$ in the as-grown state and after different gettering steps are shown. While $\mathrm{P}$ gettering raises mean lifetimes slightly from 0.2 to $0.3 \mu \mathrm{s}, \mathrm{Al}$ gettering leads to a further lifetime increase to $0.5 \mu \mathrm{s}$. In contrast, figure 9 (right) shows the same investigation for an RGS wafer with lower oxygen content $\left(4 \times 10^{17} \mathrm{~cm}^{-3}\right)$. The lower oxygen content leads to higher as-grown lifetimes, and an increased gettering effect is visible.

From the above findings it can be concluded that the formation of precipitates in the silicon bulk should be avoided in order to make best use of the gettering step for wafers used in photovoltaics (e.g., by reducing the oxygen content). Interaction between metals and oxygen leads to stable metal oxides which can hardly be dissolved. The formation of a denuded zone near the wafer surface as observed in gettering processes for wafers used for integrated circuits [110] cannot be applied for removing metals completely from the active area. Nevertheless, this effect is observed in oxygen-rich highly defected ribbon silicon materials as well, mainly near grain boundaries, which can act as internal gettering sites and as a sink for metals [111].

\section{Hydrogen passivation}

It is well known that hydrogen incorporation in crystalline silicon can reduce the recombination activity of defects and increase minority carrier lifetimes. Therefore, hydrogenation techniques play a major role in improving the material quality of defected areas within multicrystalline 

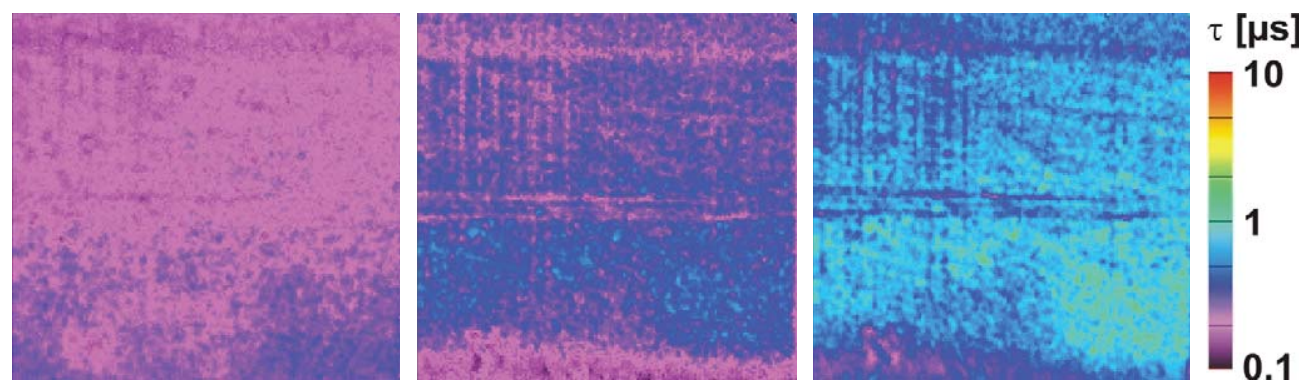

Figure 6. Mapped lifetimes for an oxygen-rich RGS wafer $\left(5 \times 5 \mathrm{~cm}^{2}\right)$ in the as-grown state (left), after $\mathrm{P}$ gettering (middle), and after $\mathrm{Al}$ gettering (right).
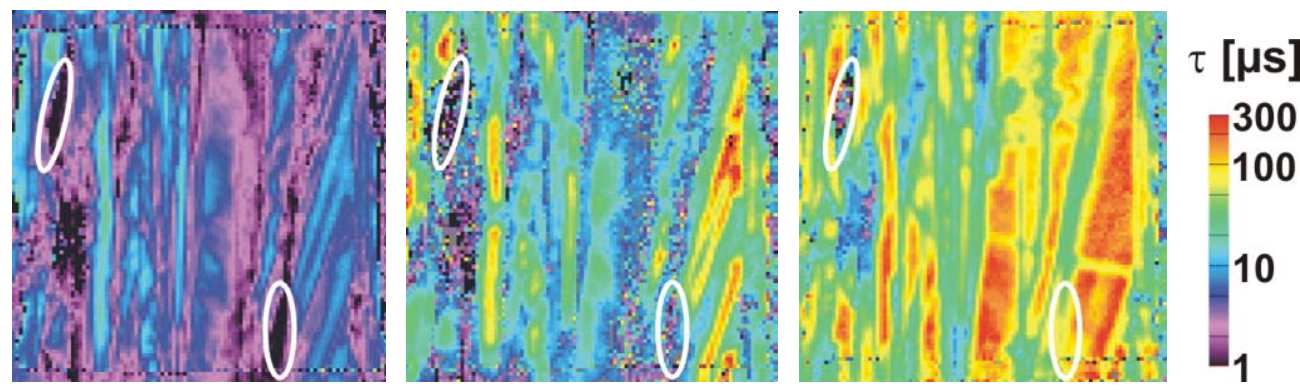

Figure 7. Bulk minority carrier lifetimes of a $5 \times 5 \mathrm{~cm}^{2} \mathrm{SR}$ wafer as grown (left), after $\mathrm{P}$ gettering (middle), and after hydrogenation (right) with identical scaling. Indicated are areas of comparable as-grown quality which significantly differ after hydrogenation [103].

wafers during solar cell processing. In this section, the mechanism of hydrogenation will be introduced together with the methods normally applied for solar cell processing. The importance of hydrogenation for highly defected ribbon silicon materials will be highlighted and material specific peculiarities of hydrogenation will be stressed.

\subsection{Interaction with defects}

Atomic hydrogen can interact with a variety of defects in the bulk of a crystalline silicon wafer (for an overview see [112-115]). The most interesting interactions for solar cell processing of defected material are obviously those reducing recombination activity of crystal defects such as dislocations, grain boundaries, and point defects with deep levels (passivation of defects $[116,117])$. The exact mechanism of passivation is still not well understood for many defects, but reaction of hydrogen with defects can be roughly classed as neutralization of impurities, which can include simple ion pairing with acceptors $\left(\mathrm{A}^{-} \mathrm{H}^{+}\right)$in p-type material where hydrogen is supposed to exist in the positive charge state $\mathrm{H}^{+}$, and passivation of unsatisfied bonds [113]. In the latter case, the defects need not have dangling bonds in the usual sense, or the presence of a nearby hydrogen atom may change the nature of the electrical activity. For both cases, the result is that there is a shift of the defect energy level from near mid-gap towards the band edges or into the valence or conduction bands, in combination with a reduction in recombination strength of the defect. The term 'passivation' implies that $\mathrm{H}$ interacts with the defect level in the band gap, rendering it inactive, and can therefore include the formation of a stable impurity $-\mathrm{H}$ or silicon- $\mathrm{H}$ bonds or a rearrangement of the defect structure. In 
certain cases, it is therefore more correct to describe the effect of hydrogen on acceptor defects as neutralization or compensation instead of passivation [113]. Nevertheless, for simplicity, in this work the interaction of $\mathrm{H}$ with all defects will be referred to as hydrogenation or $\mathrm{H}$ passivation.

\subsection{Methods for hydrogen incorporation}

There are two techniques most commonly used to introduce hydrogen into a silicon wafer: using directed ion beam sources (e.g., Kaufman ion sources [118]) or using plasma reactors. With ion beam sources, hydrogen can be deposited in well known quantities into the silicon wafer. The drawback is the damage caused by the bombardment with high energy atoms. Therefore, it is mainly plasma reactor techniques that are used for hydrogenation of solar cells. Incorporation of $\mathrm{H}$ into the silicon bulk can be achieved by direct hydrogen plasma processes [119]. In order to avoid surface damage caused by the plasma being in direct contact with the wafer, remote plasma techniques have been developed where the $\mathrm{H}$ plasma is separated from the sample [120]. This microwave induced remote hydrogen plasma (MIRHP) technique is well suited for all laboratory-type studies of hydrogenation in multicrystalline silicon for solar cells [91, 121-124].

Another plasma based method is the incorporation of hydrogen via a hydrogen-rich $\mathrm{SiN}_{x}$ layer deposited by plasma-enhanced chemical vapour deposition (PECVD [125]). Depending on the $\mathrm{NH}_{3} / \mathrm{SiH}_{4}$ ratio used for the deposition, which also influences the refractive index and absorption coefficient [126], up to $\sim 30$ at.\% can be incorporated into the $\mathrm{SiN}_{x}$ [127]. The deposited $\mathrm{SiN}_{x}$ layer is therefore not of stoichiometric composition. An annealing step following the $\mathrm{SiN}_{x}$ deposition can release atomic hydrogen into the bulk of the wafer [128130]. Direct experimental evidence of hydrogen being released from the PECVD $\operatorname{SiN}_{x}$ layer into the silicon bulk during the annealing step was found recently for monocrystalline [131] and multicrystalline silicon material [132]. Besides being a reservoir of hydrogen, the deposited PECVD SiN ${ }_{x}$ layer can simultaneously act as an antireflection coating and can provide excellent surface passivation [133]. Due to this threefold benefit for solar cell processing [134], PECVD $\mathrm{SiN}_{x}$ layers are now state of the art in modern industrial fabrication of multicrystalline solar cells.

\subsection{Passivated defects and stability}

In addition to the passivation of deep levels, shallow levels can be passivated by $\mathrm{H}$ as well. One example is the passivation of dopants such as $\mathrm{B}, \mathrm{Al}$, or $\mathrm{P}$ [135]. This is normally undesirable for solar cell processing as it changes the resistivity of the material. But as the energy needed for reactivation of the 'defect' (dopant) calculated based on a simple model [136] is $<2 \mathrm{eV}$ in these cases [112], the passivation of shallow levels or dopants is not observed for passivation temperatures in the range of $300-450{ }^{\circ} \mathrm{C}$ which is typically used for many experiments [137, 138]. Activation energies for other $\mathrm{H}-\mathrm{defect}$ complexes, with the defects being e.g., $\mathrm{Au}, \mathrm{Pd}, \mathrm{Pt}, \mathrm{Cu}, \mathrm{Ni}, \mathrm{Ag}, \mathrm{Fe}$, and grain boundaries (2.2-2.5 eV), as well as dislocations (3.1 eV [139]) causing deep levels in the band gap are significantly higher. Therefore, reactivation of these defects takes place at higher temperatures of about $400^{\circ} \mathrm{C}$ [112], which is in good agreement with annealing experiments carried out with hydrogenated solar cells $[122,132,140,141]$. This makes hydrogen passivation of recombination active deep level defects in defected solar cell material quite thermally stable.

\subsection{Hydrogenation of EFG and SR materials}

The benefit of hydrogenation in EFG material was manifested in early studies by a reduction of the recombination activity of dislocations and grain boundaries after ion 
implantation [116, 142]. Other, more recent studies revealed the effect of hydrogenation on bulk lifetimes for EFG and SR materials by using remote plasma techniques [102, 103, 105, 106] or passivation from PECVD $\operatorname{SiN}_{x}$ layers [100, 104]. It was found that hydrogenation using MIRHP causes a larger increase in bulk lifetimes than observed for Al or P gettering steps. Whereas gettering techniques improve mainly good quality areas of the as-grown wafer, hydrogen treatment can improve areas of all qualities significantly. Nevertheless, the achievable final lifetime after hydrogenation is not a function of lifetime in the asgrown state alone $[102,103,105,106]$. This clearly demonstrates the complex situation of inhomogeneous defect distribution in ribbon silicon. The efficiency of hydrogenation is strongly dependent on the underlying defects. Figure 7 shows lifetimes of a SR wafer in the as-grown state, after Al gettering, and after MIRHP hydrogenation. Indicated are areas of comparable starting lifetimes, resulting in areas of significantly different lifetimes after the gettering and hydrogenation step. As dislocations contaminated with precipitates seem to play the major role in recombination activity, an explanation for the different behaviours is the change in chemical composition of these precipitates. Dependent on the nature of the precipitates $[66,67]$, hydrogenation is more or less effective in reducing the recombination strength.

It can be shown that hydrogenation is stable under illumination, provided that a gettering step precedes the hydrogenation step [102]. Without this gettering step, lifetimes tend to decrease slightly upon illumination. The reason for this instability is unclear, but it could involve activation of transition metal based defects such as $\mathrm{Fe}-\mathrm{B}$ or $\mathrm{Cr}-\mathrm{B}$ ones.

Furthermore, an increased passivation effect has been observed when $\mathrm{Al}$ is present at the wafer surface during hydrogenation of a PECVD $\operatorname{SiN}_{x}$ layer [101, 134, 143]. This synergetic effect, which leads to larger increases in carrier lifetimes than separate gettering and hydrogenation steps, is possibly explained by increased vacancy formation due to the $\mathrm{Al}$ alloying process and enhanced hydrogen diffusivity [143]. This theory could not be proven, as experiments to determine vacancy concentrations before and after $\mathrm{Al}$ alloying did not show an increase in $\mathrm{Si}_{\mathrm{V}}$ [144].

The effect of gettering and hydrogenation steps on lifetimes in EFG and SR materials is shown again in figure 8 . Data have been obtained on wafers fabricated according to processing sequences presented in more detail elsewhere [102]. Wafer 1 shows slight instability of the hydrogenation after illumination without a preceding gettering step, especially for areas of high lifetimes. Wafers 2 and 3 indicate stability of hydrogenation if a P (wafer 2) or Al gettering step (wafer 3 ) precedes the hydrogenation. Additionally, the effect of higher lifetimes resulting from a combination of gettering and hydrogenation can be seen. Combination of $\mathrm{P}$ and $\mathrm{Al}$ gettering (cogettering) seems to be more effective than $\mathrm{P}$ or Al gettering alone, but does not lead to significantly higher lifetimes upon hydrogenation (wafer 4).

Retention of hydrogen at the defects is important for maintaining the passivation properties. For temperatures of $>400{ }^{\circ} \mathrm{C}$ reactivation of recombination activity can be observed, due to thermal activation. Therefore, cooling rates after $\mathrm{H}$ passivation are important. Hydrogenation from PECVD $\mathrm{SiN}_{x}$ layers with annealing temperatures in the range of $700-850{ }^{\circ} \mathrm{C}$ can be significantly affected by cooling-down ramps. Experiments using rapid thermal processing (RTP) in combination with PECVD $\mathrm{SiN}_{x}$ layers revealed that higher lifetimes can be achieved by using fast cool-down ramps [145, 146].

\subsection{Hydrogenation in RGS material}

Hydrogen passivation of defects in RGS material is also important; as-grown material lifetimes are lower than those for EFG and SR materials (table 2). For material with high interstitial 




Figure 8. Histograms of $\mu \mathrm{PCD}$ lifetime mappings carried out on four EFG wafers $\left(5 \times 5 \mathrm{~cm}^{2}\right)$ after different processing steps. Wafers 2 and 3 are adjacent and reveal similar crystal grain structures; the same holds true for wafers 1 and 4. More details are given elsewhere [102].

oxygen content, the formation of new donors was found to increase the density of bulk trap states drastically [79], further reducing material quality. A hydrogenation step carried out afterwards was shown to cause the material quality to recover, proving that new donors can be effectively passivated by hydrogen [79]. Nevertheless, the high oxygen content seems to hinder the effectiveness of hydrogenation. D profiles obtained for RGS material only differing in interstitial oxygen concentration showed a reduced diffusion for higher oxygen contents [138]. This effect was also observed for other materials [91] and can be explained by oxygen lowering the propensity for generation of vacancies [147]. Alternative models are presented in the next paragraph. Whereas for low oxygen materials such as EFG ones, hydrogen diffuses through the whole wafer within $\sim 30 \mathrm{~min}$ at $350{ }^{\circ} \mathrm{C}$, this takes several hours in the case of oxygen-rich RGS material [91].

Lifetimes for oxygen-rich materials have been limited to values of $<1 \mu \mathrm{s}$, even after optimized hydrogenation steps [86]. A lowering of the overall oxygen content to values of $\sim 5 \times 10^{17} \mathrm{~cm}^{-3}$ in recently obtained RGS material [58] led to lifetimes of $\sim 3 \mu \mathrm{s}$ after gettering and hydrogenation. A positive side effect is that hydrogenation time in this case can be significantly shorter, as diffusion is faster.

\subsection{Diffusion of $H$ in defected silicon}

The diffusion kinetics of hydrogen plays an important role in defected crystalline silicon material. Van Wieringen and Warmoltz [148] determined diffusivities in monocrystalline 

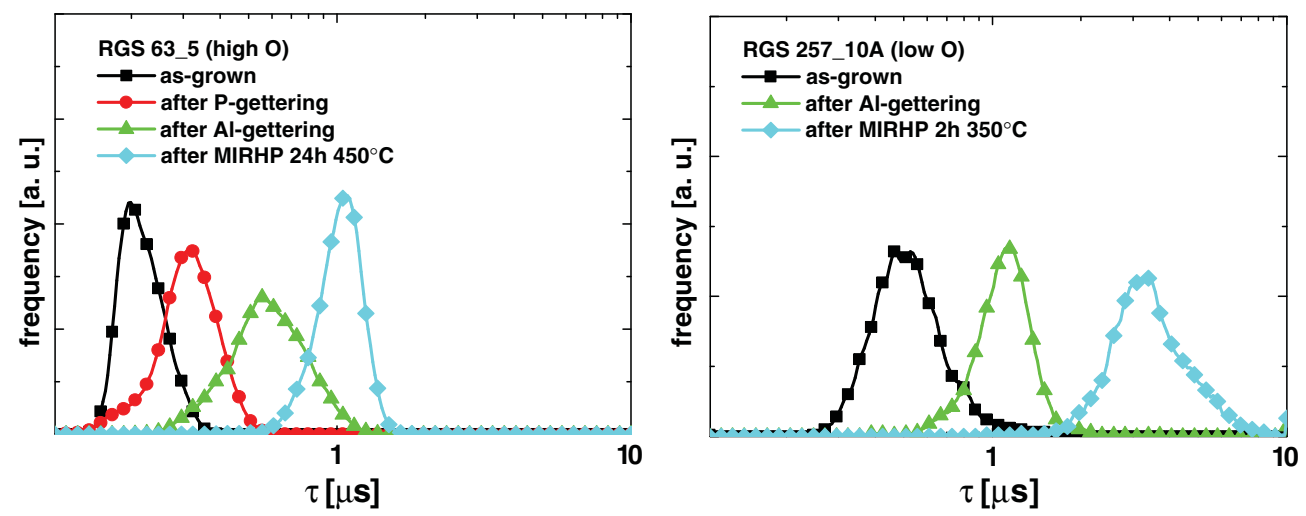

Figure 9. Histograms of $\mu \mathrm{PCD}$ lifetime mappings carried out for two RGS wafers $\left(5 \times 5 \mathrm{~cm}^{2}\right)$ with high $\left(3 \times 10^{18} \mathrm{~cm}^{-3}\right.$, left $)$ and reduced oxygen concentration $\left(4 \times 10^{17} \mathrm{~cm}^{-3}\right.$, right $)$ after different processing steps. While lifetime enhancement is limited for the high oxygen wafer due to internal gettering and trapping of hydrogen, higher lifetimes can be reached for lower oxygen concentrations.

Table 3. Concentrations of $\mathrm{Si}_{\mathrm{V}}$ and interstitial oxygen in various crystalline ribbon silicon materials (from [144, 151]).

$\begin{array}{llll}\text { Material } & \begin{array}{l}\text { As-grown }\left[\mathrm{O}_{\mathrm{i}}\right] \\ \left(\mathrm{cm}^{-3}\right)\end{array} & \begin{array}{l}{\left[\mathrm{O}_{\mathrm{i}}\right] \text { after } \mathrm{POCl}_{3}} \\ \text { diffusion }\left(\mathrm{cm}^{-3}\right)\end{array} & \begin{array}{c}{[\mathrm{Siv}] \text { after } \mathrm{POCl}_{3}} \\ \text { diffusion }\left(\mathrm{cm}^{-3}\right)\end{array} \\ \text { EFG } & <10^{17} & <10^{17} & 10 \times 10^{12} \\ \text { SR } & <10^{17} & <10^{17} & \sim 10 \times 10^{12} \\ \text { RGS, high [O] } & 29 \times 10^{17} & 4 \times 10^{17} & <1 \times 10^{12} \\ \text { RGS, low [O] } & 4 \times 10^{17} & 3 \times 10^{17} & 20-30 \times 10^{12}\end{array}$

silicon at high temperatures. Extrapolation to lower temperatures from these data leads to diffusion constants for hydrogen of $1.1 \times 10^{-6} \mathrm{~cm}^{2} \mathrm{~s}^{-1}$ at $350{ }^{\circ} \mathrm{C}$ and $3.8 \times 10^{-5} \mathrm{~cm}^{2} \mathrm{~s}^{-1}$ at $750^{\circ} \mathrm{C}$. From these data we should expect diffusion of hydrogen through the entire wafer within $<30 \mathrm{~min}$ at $350^{\circ} \mathrm{C}$ or $<20 \mathrm{~s}$ at $750^{\circ} \mathrm{C}$. While this seems to be the case for EFG and SR materials [91, 149], hydrogen diffusivity in oxygen-rich materials is slowed down [91, 138, 150]. One explanation could be the reduced vacancy concentration in the presence of a high oxygen content $[132,151]$ (table 3). According to this model, vacancies can dissociate immobile hydrogen molecules to atomic hydrogen [152, 153]. A low vacancy concentration would therefore result in increased molecule formation reducing the atomic hydrogen content available for diffusion and passivation. The formation of immobile hydrogen molecules $[112,154]$ might therefore be hindered in materials with higher vacancy concentration such as EFG and SR materials, resulting in a faster diffusion.

A further model proposed by Sopori et al [147] favours the formation of a $\mathrm{H}-\mathrm{Si}_{\mathrm{V}}$ complex and its rapid diffusion through the lattice $[155,156]$.

Another explanation of reduced diffusivity in oxygen-rich materials is a direct interaction between $\mathrm{H}$ and $\mathrm{O}$, resulting in trapping of hydrogen. Interaction between $\mathrm{H}$ and interstitial oxygen is known to enhance the diffusivity of oxygen and increase the formation of thermal donors [157, 158]. A proposed trapping of hydrogen near interstitial oxygen [158] could therefore explain the observed low diffusivities of hydrogen in oxygen-rich material.

On the other hand, it is known that hydrogen can passivate thermal donors [159] as well as new donors [79] indicating a direct coupling with the concentration of these defects. 
High oxygen concentrations should thus lead to trapping of hydrogen, especially when the trap concentration is large as compared to the hydrogen concentration. Trapping due to high $\left(\sim 10^{18} \mathrm{~cm}^{-3}\right)$ oxygen concentrations can therefore explain the prolonged times needed for hydrogen diffusion through the whole wafer, either by trapping near interstitial oxygen or at thermal or new donors. In this model [132] the diffusivity of hydrogen is dependent on the amount of oxygen precipitates (e.g. new donors) present and their surface area, as the interaction (trapping) between hydrogen and precipitate is assumed to take place via its surface. In this way the observed variations in hydrogen diffusivity for materials differing in oxygen concentration can be explained if the thermal history is taken into account, which determines the size and amount of the precipitates [132].

\section{Ribbon silicon solar cells}

Fabrication of solar cells using ribbon silicon wafers has to be adapted to the material needs in order to reach satisfactory conversion efficiencies. As for all multicrystalline silicon wafers, material quality should be improved during cell processing to cope with the defect structure present in the as-grown material. This is in contrast to the case for monocrystalline float zone material, where the main task is to maintain the high as-grown material quality during processing steps. It was shown in the previous sections that ribbon material quality can be substantially improved by gettering and hydrogenation. The implementation of these steps into the solar cell process is therefore crucial, as the efficiency obtainable for solar cells from a given material is important for cost-effectiveness.

\subsection{Laboratory-type and industrial-type processing}

When considering efficiencies, two types of cell process have to be distinguished, namely laboratory-type and industrial-type processing. Laboratory-type processing normally results in small area cells $\left(\sim 4 \mathrm{~cm}^{2}\right)$ and makes use of processing steps regardless of the cost per wafer. The purpose is usually to determine the material potential or to fundamentally develop and test new processing sequences in a very controlled way. Contacts are normally formed by evaporation techniques to achieve good contact resistance and to enable a good spectral response in the short wavelength region as high emitter sheet resistances can be used. The front metal grid is usually defined by a photolithography step to minimize grid shadowing losses, which are in the region of $4 \%$.

On the other hand, industrial-type processing simulates the efficiency obtainable in large scale production. Therefore, significantly larger cell areas, normally $\geqslant 100 \mathrm{~cm}^{2}$, are used, which is closer to cell formats commercially used in industry. Processing steps are restricted by consideration of costs which means that e.g. for front contact formation, generally thick film metallization is applied (the only other alternative currently used in industry in significant volumes is the buried grid technology [160]). Thick film metallization via deposition of metalcontaining pastes and subsequent firing to obtain ohmic contacts results in higher shadowing losses $(\sim 7 \%)$ and currently does not allow as high emitter sheet resistivities as are used for laboratory-type evaporation techniques without selective emitter structures. Efficiencies are therefore significantly lower for industrial-type processing. Another reason for the lower record values of industrial-type cells is the presence of inhomogeneities in the material quality, especially when variations are on the same scale as the cell size used for laboratory-type processing.

Examples of two typical processes are shown schematically in figure 10. In both processes, gettering and hydrogenation steps are implemented. $\mathrm{P}$ gettering takes place during $\mathrm{P}$ diffusion. For laboratory-type processing, $\mathrm{POCl}_{3}$ is usually used as the dopant source in an open tube 
furnace resulting in an emitter on both front and rear sides. For industrial-type processes, an alternative to using $\mathrm{POCl}_{3}$ is using one-sided diffusion, e.g. by using a spray-on or spinon dopant and diffusion in a belt furnace. Gettering action might be reduced in the latter case as only one surface acts as a sink for metal impurities [161, 162]. Al gettering in a laboratory-type process can be obtained by evaporation of $\mathrm{Al}(\sim 2 \mu \mathrm{m})$ followed by alloying at temperatures above the eutectic point of $\mathrm{Al} / \mathrm{Si}$, normally in the range of $800^{\circ} \mathrm{C}$ for $\sim 30 \mathrm{~min}$. This step simultaneously serves to overcompensate the parasitic back emitter and to form a BSF to hinder recombination of minority charge carriers at the back of the cell. Al gettering for industrial-type processes is limited to the firing step for contact formation.

Hydrogenation can be applied via remote plasma techniques on finished cell structures for laboratory-type processing. In this way, the beneficial effect can be quantified directly on the cell level. The only limitation is that the temperature load is limited due to possible in-diffusion of metals from the front metallization into the emitter, which results in shunt formation. This limits hydrogenation to temperatures of $<450{ }^{\circ} \mathrm{C}$ and durations of $\sim 1 \mathrm{~h}$ (dependent on temperature [163]). This restriction can be overcome if hydrogenation is applied prior to contact formation [164]. Hydrogenation for industrial-type processing is generally carried out using hydrogen-rich PECVD $\mathrm{SiN}_{x}$ layers. The hydrogen stored in the $\mathrm{SiN}_{x}$ is released into the bulk during the firing step, which has to be designed properly in order to also provide both a good contact and BSF formation.

An evaporated double-layer antireflective coating (DARC; e.g. $\mathrm{ZnS} / \mathrm{MgF}_{2}$ ) reduces reflection losses in the case of laboratory-type processing, whereas for industrial-type processes the PECVD SiN acts as a single-layer ARC.

\subsection{EFG and SR solar cells}

Both EFG and SR wafers are fabricated commercially and solar cells have been processed on a large scale, industrial basis since 1994 (EFG material) and 2001 (SR material). For EFG in particular, the research was intensive and publication of solar cell results with efficiencies exceeding 14\% using a laboratory-type process dates back to 1983 [142]. Further progress in laboratory-type efficiency improvement was comparatively slow for EFG material until the mid-1990s, as can be seen from figure 11. From this time on, SR and EFG material record efficiencies have developed in parallel, again demonstrating their comparable material quality.

As material quality is inhomogeneous even after gettering and hydrogenation (see figure 7), solar cell results are affected by both good and bad areas. Cell performance in areas of low diffusion length is limited due to recombination in the bulk, whereas rear surface recombination, $S_{\mathrm{b}}$, can limit carrier collection in good quality areas.

The Al gettering step in the laboratory-type process shown in figure 10 with evaporation of $\mathrm{Al}$ (thickness 1-2 $\mu \mathrm{m}$ ) is effective in removing metal atoms, but results only in minor values for $S_{\mathrm{b}}$ because the BSF thickness is $<1 \mu \mathrm{m}$ and the peak concentration of $\mathrm{Al}$ in the BSF is around $5 \times 10^{18} \mathrm{~cm}^{-3}$ [166]. To cope with this restriction, thicker BSFs obtained using screen-printing and firing of $\mathrm{Al}$ paste have been implemented in laboratory-type processing [108] resulting in BSF thicknesses of 8-10 $\mu \mathrm{m}$. In this way, values for $S_{\mathrm{b}}$ in the range $300-600 \mathrm{~cm} \mathrm{~s}^{-1}$ can be obtained for material with bulk resistivities of $3 \Omega \mathrm{cm}$ [166]. Areas with high $L_{\text {diff }}$ benefit especially from the lower back surface recombination (figure 12), and a significant increase in efficiency for laboratory-type processes was obtained [108].

Areas of lower material quality are of special interest, as these regions normally limit cell efficiency. Lower quality areas can be improved mainly by hydrogenation $[102,105]$; therefore bulk defect passivation kinetics has been studied intensively. It was shown that retention of hydrogen at the defect sites can only be achieved for temperatures of $<400^{\circ} \mathrm{C}$ if no capping layer is present $[140,167]$. Similar results have been obtained for cells with a $\mathrm{SiN}_{x}$ layer on 


\begin{tabular}{|c|c|}
\hline Lab-type process & Industrial-type process \\
\hline defect etching / texture & defect etching \\
\hline P-diffusion ( $90 \Omega / s q)$ & 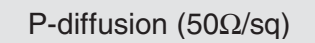 \\
\hline P-glass etching & P-glass etching \\
\hline thermal oxidation & PECVD SiN deposition \\
\hline Al-gettering & edge isolation (plasma) \\
\hline photolithography & thick film front contact \\
\hline $\mathrm{Ti} / \mathrm{Pd} / \mathrm{Ag}$ front contact & thick film back contact \\
\hline Al rear contact & co-firing \\
\hline electroplating & \\
\hline cell isolation (dicing) & \\
\hline hydrogenation & \\
\hline DARC deposition & \\
\hline
\end{tabular}

Figure 10. Typical solar cell fabrication sequences used for laboratory-type processing (left) and industrial-type processing (right).


Figure 11. Progress in record efficiencies for EFG and SR solar cells using laboratory-type (left) and industrial-type processing (right). Some of the data are from [165].

top of the emitter $[100,141]$. To ensure retention of hydrogen at the defect sites subsequent to hydrogenation, temperature ramps are critical. This is especially important for hydrogenation via a PECVD $\mathrm{SiN}_{x}$ layer, as the optimum temperature for hydrogenation is between 650 and $800^{\circ} \mathrm{C}$, depending on the frequency used for plasma excitation during $\operatorname{SiN}_{x}$ deposition and whether there is $\mathrm{Al}$ present on the back $[146,168]$. At these elevated temperatures, hydrogen can be released from the defect site and the recombination strength of the defect can be restored. Studies using rapid thermal processing (RTP) demonstrate that retention of hydrogen is a function of annealing time and cooling rates [104, 149, 165, 169]. Optimum passivation was achieved by annealing at $750^{\circ} \mathrm{C}$ for just $1 \mathrm{~s}$ (excluding the time for ramping up and down). It is interesting to compare this result with the hydrogen diffusivity data of van Wieringen and Warmoltz [148] on monocrystalline silicon presented above. Extrapolation of their data reveals that a few seconds of annealing at $750{ }^{\circ} \mathrm{C}$ should be sufficient for the 

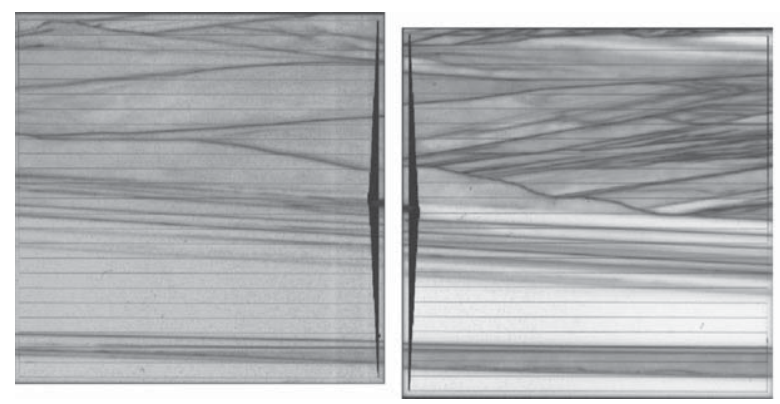

IQE $(980 \mathrm{~nm})$

Figure 12. The influence of $S_{\mathrm{b}}$ on the internal quantum efficiency (IQE) at $980 \mathrm{~nm}$ for two adjacent $4 \mathrm{~cm}^{2}$ SR cells originating from the same wafer with BSF thicknesses of $<1 \mu \mathrm{m}$ (left) and $8-10 \mu \mathrm{m}$ (right). Good quality areas benefit from the lower $S_{\mathrm{b}}$ (right). More details appear in $[108,166]$.

hydrogen to penetrate the whole bulk of the wafer. It is possible that this rapid diffusivity is enhanced by the high $\mathrm{Si}_{\mathrm{V}}$ concentration present in EFG and SR materials.

Record efficiencies of $18.2 \%$ for EFG material and $17.9 \%$ for SR material were obtained using laboratory-type processing [167]. Cells processed according to this process show light induced degradation (open symbols in figure 11, [170]). Stable efficiencies under illumination of $16.7 \%$ for EFG material and 17.7 for SR material have been published for a similar process [108].

Large area solar cells processed according to an industrial-type fabrication scheme show significantly lower efficiencies. Record values of $15.3 \%$ for EFG material $\left(10 \times 10 \mathrm{~cm}^{2}\right.$ [171] and $15.6 \%$ for SR material $\left(8 \times 10 \mathrm{~cm}^{2}\right.$ [172]) have been reported. One significant limitation, apart from higher shadowing losses and lower sheet resistivity, is the lack of an efficient surface texture for EFG and SR materials. As alkaline texturing cannot be applied due to anisotropic preferential etching at grain boundaries, reflection after cell processing with standard PECVD $\mathrm{SiN}_{x}$ as a single-layer antireflection coating is significantly higher than for other materials. Therefore, the properties of the glass used for encapsulation of the cells play an important role. By choosing glass with a modified surface, cell efficiency could be increased for an $8 \times 10 \mathrm{~cm}^{2}$ SR cell from $15.4 \%$ after industrial-type cell processing to $15.8 \%$ after encapsulation [172].

\subsection{RGS solar cells}

Cell processing of RGS wafers must be adapted to the wafer surface morphology. There are two main differences compared to the case for EFG and SR wafers. Firstly, whereas the latter exhibit uneven surfaces on both sides, RGS wafers have a flat back due to the use of a substrate during crystallization. Secondly, impurities can segregate in the liquid-solid interface and are frozen at the RGS wafer front, which is uneven. Therefore, this side has to be treated prior to cell processing to remove this impurity-rich layer. An elegant way to remove this layer and to flatten the wafer front in one step is mechanical planarization [173] followed by a damage etch. This results in wafers that are flat on both sides and standard screen-printing techniques can be applied for industrial-type processing. An alternative is to etch off this layer. Progress in laboratory-type processing can be seen in figure 13 and was achieved by making improvements in both material quality and cell processing. Efficiencies are significantly lower as compared to figure 11, mainly due to the lower values of $L_{\text {diff }}$ caused by higher defect densities.

For oxygen-rich material, $L_{\text {diff }}$ is restricted to values of $<50 \mu \mathrm{m}$ [58], even after optimized hydrogenation [164]. To cope with this limitation and to increase the current density despite the low diffusion length, a macroscopic mechanical texture of the front surface has been applied. This texture results in V-grooves with depths of $\sim 60 \mu \mathrm{m}$. The benefit from using 
this procedure for the RGS solar cell is threefold: reflection losses are reduced, carriers are generated closer to the wafer surface due to the inclined penetration of the light, and the collection probability of generated charge carriers is enhanced due the reduced distance between the site of generation and the emitter, which follows the V-grooved surface [174]. The beneficial effect of the grooving is dependent on $L_{\text {diff }}$ and in the range of $6 \%_{\text {rel }}-8 \%_{\text {rel }}$ efficiency increase for $L_{\text {diff }}<100 \mu \mathrm{m}$.

As described earlier, hydrogenation in oxygen-rich RGS material is reduced compared to that in EFG and SR materials, and even several hours of passivation at $450{ }^{\circ} \mathrm{C}$ are not sufficient for the hydrogen to penetrate the whole wafer [132]. Therefore remote plasma passivation has to be applied prior to metallization, in contrast to the case in the processing scheme used for EFG and SR wafers, shown in figure 10. Optimization of this step as regards temperature and duration in combination with a V-grooved surface texture led to efficiencies of $12.5 \%$ [164] and more recently $13.2 \%$ on $2 \times 2 \mathrm{~cm}^{2}$ cells [175] in oxygen-rich material.

For practical reasons, RGS wafers were cut down from $8.6 \times 13$ to $5 \times 5 \mathrm{~cm}^{2}$ for industrialtype processing. Using this wafer format, efficiencies of $10.5 \%$ have been reached using RGS material with a high oxygen content [58]. This process involved a remote plasma passivation step in addition to hydrogenation via PECVD $\mathrm{SiN}_{x}$ and firing. Reducing the oxygen content in RGS wafers results in significantly higher charge carrier lifetimes and therefore higher diffusion lengths, as was shown in the previous sections. As a consequence, short circuit current densities on untextured wafers can be enhanced from $\sim 24$ to $>28 \mathrm{~mA} \mathrm{~cm}^{-2}$ and open circuit voltages increase from 565 to $>580 \mathrm{mV}$ in solar cells fabricated from this material, resulting in efficiencies in the $12-13 \%$ region [175].

A clear efficiency increase can also be expected for the low oxygen material in laboratorytype processing.

\subsection{Summary}

Solar cells made from ribbon silicon wafers are more cost-effective when efficiencies are in the same range as for cells from costlier wafers originating from ingots. Record efficiencies for EFG and SR cells in the range of 17\%-18\% are comparable to those for the best cells fabricated from multicrystalline wafers from ingots when laboratory-type processes of the same complexity are used. The same is true for industrial-type processing, with record efficiencies between $15 \%$ and $16 \%$ and mean values between $14 \%$ and $15 \%$ for EFG solar cells in production [171]. From these data, it can be concluded that solar cells from EFG or SR wafers have a significant advantage as regards cost per $\mathrm{Wp}$, provided that a comparable yield is achieved.

RGS wafers have the advantage of a more cost-effective fabrication due to the high production speed. The expectation is that, even if the efficiency is somewhat lower, the introduction of RGS material would further reduce the costs per Wp of PV modules. The improvements in wafer quality and the increased understanding of the interaction between defects and solar cell processing makes it very likely that higher efficiency values will be reached soon. The target is the $14 \%$ region with industrial-type processes in the near future, a prospect that seems to be promising if the dynamic efficiency development shown in figure 13 is considered.

In addition to the cost-effectiveness of silicon ribbons, the energy payback time (i.e. the time needed to produce the amount of energy that was consumed during the manufacturing of a solar system) is drastically reduced. In a recent life-cycle analysis of crystalline silicon wafer based PV systems it was demonstrated that the energy payback times can be reduced from 4.3 years (based on cut multicrystalline wafers) to 2.0 years by the use of RGS ribbons for systems in central Europe [176]. 


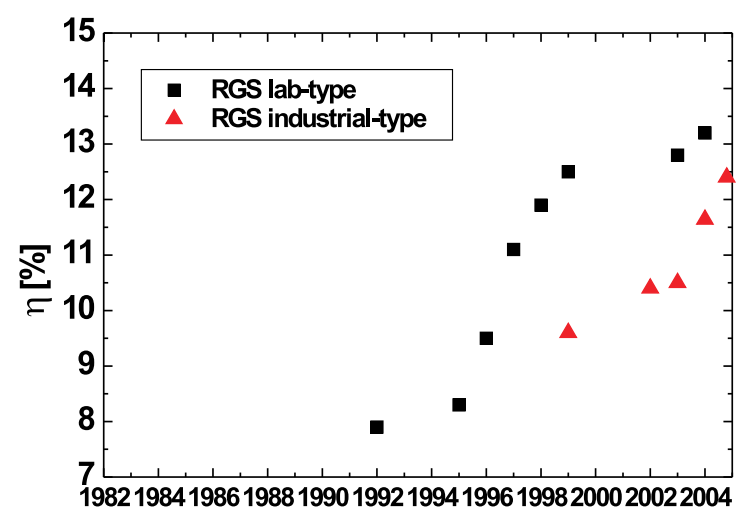

Figure 13. Progress in record efficiencies of RGS solar cells using laboratory-type and industrialtype processing.

All silicon ribbon technologies make very effective use of the increased understanding of material defects, their interaction, and their behaviour during solar cell processing. The material development is mainly based on a strategy where 'the' limiting defect structure is analysed, eliminated by process development, or reduced in impact by effective use of passivation or gettering during solar cell processing. The result is the appearance of a different limitation on an improved efficiency level. This strategy resulted in EFG and SR ribbon material with minority carrier diffusion lengths comparable to or larger than the wafer thickness. The same strategy is applied for fast ribbon technologies such as the RGS method, but further improvements are needed to make it a competitive technology. As the RGS method can make use of existing knowledge, it can be expected that the quality development will close in on existing technologies.

Key technologies for the use of lower quality, cost-effective silicon materials for solar cells are the PECVD SiN processes with the inherent hydrogen passivation during the metal firing step, which has become the industrial state of the art. The challenge is to optimize the applicable process parameters in the limited time and temperature range to take full advantage of the twofold functionality of antireflection coating and material improvement by bulk defect passivation. In order to do this, understanding of hydrogen diffusion in relation to the material parameters such as the oxygen content is highly important. The research done in the field of interaction between hydrogen, metal impurities, and oxygen and carbon contaminations is very important for understanding the processes and reactions involved, and defining process dependent tolerance limits for the material quality. The same holds for gettering steps during emitter formation and metallization firing.

With limitation of the silicon supply on the horizon, knowledge about the sensitivity of solar cell processes to metallic impurities is needed to allow making use of lower quality solar grade silicon sources for ribbon technologies.

Due to the large economical and technological potential of silicon ribbons, their application in solar wafer production will be a major milestone in PV cost reduction. It is thus very likely that silicon wafer based PV module manufacturing will maintain the cost advantage over other upcoming technologies and therefore its role as the major PV technology.

Current trends for multicrystalline wafer based solar cells are moving towards thinner and larger wafers. Ribbon silicon based wafer technologies have to deal with these developments in the future to maintain their cost-effectiveness. Whereas thin EFG, SR, and RGS wafers have already been produced on a laboratory scale with thicknesses of $<200 \mu \mathrm{m}$, their industrial application remains an area of ongoing research. 
Producing larger area square wafers should not be a general problem for the RGS technology, due to the local growth supported by a rigid substrate, whereas increasing the wafer width might be more problematic in EFG and SR technologies. Nevertheless, the cell area for EFG and SR wafers can be easily increased by using rectangular wafers with constant width and increased length.

\section{References}

[1] Schmela M 2004 Photon Int. 346

[2] SEMI M1-0704, Specifications for Polished Mono-Crystalline Silicon Wafers, Semiconductor Equipment and Materials International (www.semi.org)

[3] SEMI M6-1000, Specifications for Silicon Wafers for Use as Photovoltaic Solar Cells, Semiconductor Equipment and Materials International (www.semi.org)

[4] Phillips M J 1986 Summary of the Flat-Plate Solar Array Project Documentation: Abstracts of Published Documents, 1975 to 1986 DOE/JPL-1012-76

[5] Koch W, Hässler C, Höfs H-U, Müller A and Schwirtlich I A 1997 Solid State Phenom. 57/58 401

[6] Ciszek T F 1996 High Purity Silicon IV ed C L Claeys, P Rai-Choudhury, P Stallhofer and J E Maurtis (Pennington, MN: The Electrochemical Society) p 76

[7] Sarti D and Einhaus R 2002 Sol. Energy Mater. Sol. Cells 7227

[8] de Vos A 1992 Endoreversible Thermodynamics of Solar Energy Conversion (Oxford: Oxford University Press)

[9] Zhao J, Wang A and Green M A 1999 Progr. Photovolt. Res. Appl. 7471

[10] Shockley W and Read W T 1952 Phys. Rev. 87835

[11] Hall R N 1952 Phys. Rev. 87387

[12] Fally J, Fabre E and Chabot B 1987 Rev. Phys. Appl. 22529

[13] Davis J R, Rohatgi A, Hopkins R H, Blais P D, Rai-Choudhury P, McCormic J R and Mollenkopf H C 1980 IEEE Trans. Electron Devices 27677

[14] Dermatis S N and Faust J W 1963 IEEE Trans. Commun. Electron. 8294

[15] Boatman J and Goundry P 1967 Electrochem. Technol. 598

[16] Ciszek T F 1972 Mater. Res. Bull. 7731

[17] Koyanagi T 1976 Proc. 12th IEEE PVSC (Baton Rouge) (US: IEEE, Library of Congress) p 627

[18] Belouet C 1987 J. Cryst. Growth 82110

[19] Lesk I A, Baghadadi A, Gurtler R W, Ellis R J, Wise J A and Coleman M G 1976 Proc. 12th IEEE PVSC (Baton Rouge) (US: IEEE, Library of Congress) p 173

[20] Heaps J D, Maciolek R B, Zook J D and Scott M W 1976 Proc. 12th IEEE PVSC (Baton Rouge) (US: IEEE, Library of Congress) p 147

[21] Ciszek T F and Schwuttke G H 1977 J. Cryst. Growth 42483

[22] Ciszek T F and Hurd J L 1980 Proc. 14th IEEE PVSC (San Diego) (US: IEEE, Library of Congress) p 397

[23] Kim K M, Berkman S, Duffy M T, Bell A E, Temple H E and Cullen G W 1977 Silicon Sheet Growth by the Inverted Stepanov Technique DOE/JPL-954465

[24] Tsuya N, Arai K I, Takeuchi T, Ohmor K, Ojima T and Kuroiwa A 1980 J. Electron. Mater. 9111

[25] Ciszek T F, Hurd J L and Schietzelt M 1982 J. Electrochem. Soc. 1292838

[26] Bates H E and Jewett D M 1981 Proc. 15th IEEE PVSC (Kissimmee) (US: IEEE, Library of Congress) p 255

[27] Grabmaier J G and Falckenberg R 1990 J. Cryst. Growth 104191

[28] Beck A, Geissler J and Helmreich D 1987 J. Cryst. Growth 82127

[29] Eyer A, Schillinger N, Reis I and Räuber A 1990 J. Cryst. Growth 104119

[30] Lange H and Schwirtlich I 1990 J. Cryst. Growth 104108

[31] Suzuki M, Hide I, Yokoyama T, Matsuyama T, Hatanaka Y and Maeda Y 1990 J. Cryst. Growth 104102

[32] Maeda Y, Yokoyama T, Hide I, Matsuyama T and Sawaya K 1986 J. Electrochem. Soc.: Solid State Sci. Technol. 133440

[33] Komatsu Y, Koide N, Yang M-J, Nakano T, Nagano Y, Igarashi K, Yoshida K, Yano K, Hayakawa T, Taniguchi H, Shimizu M and Takiguchi H 2003 Sol. Energy Mater. Sol. Cells 74513

[34] Konagai M 2002 Proc. 29th IEEE PVSC (New Orleans) (US: IEEE, Library of Congress) p 38

[35] Ciszek T F 1984 J. Cryst. Growth 66655

[36] Wald F W 1981 Crystals: Growth, Properties, and Applications vol 5, ed J Grabmaier (Berlin: Springer) p 147

[37] Sachs W M, Ely D and Serdy J 1987 J. Cryst. Growth 82117 
[38] Culik J S, Faller F, Goncharovsky I S, Rand J A and Barnett A M 2001 Proc. 17th EC PVSEC (Munich) (Munich: WIP) p 1347

[39] Ciszek T F 1976 J. Appl. Phys. 47440

[40] Kalejs J P 1993 J. Cryst. Growth 128298

[41] Wallace R J, Hanoka J I, Narasimha S, Kamra S and Rohatgi A 1997 Proc. 26th IEEE PVSC (Anaheim) (US: IEEE, Library of Congress) $\mathrm{p} 99$

[42] Cho S H and Sunderland J E 1969 J. Heat Transfer 91c 421

[43] Rao C V H N, Cretella M C, Wald F V and Ravi K V 1980 J. Cryst. Growth 50311

[44] Garone L C, Hari Rao C V, Morrison A D, Surek T and Ravi K V 1976 Appl. Phys. Lett. 29511

[45] Briglio A, Dumas K, Leipold M and Morrison A 1986 Flat Plate Solar Array Project: Volume III Silicon Sheets and Ribbons DOE/JPL 1012-125

[46] Hull R 1999 Properties of Crystalline Silicon (London: Inspec)

[47] Janoch R E, Anselmo A P, Wallace R L, Martz J, Lord B E and Hanoka J I 2000 Proc. 28th IEEE PVSC (Anchorage) (US: IEEE, Library of Congress) p 1403

[48] Hirata H and Hoshikawa K 1980 Japan. J. Appl. Phys. 191573

[49] Schei A, Tuset J and Tveit H 1998 Production of High Silicon Alloys (Trondheim: Tapir Forlag)

[50] Li J-G and Hausner H 1995 Scr. Metall. Mater. 32377

[51] Li J-G and Hausner H 1996 J. Am. Ceram. Soc. 97873

[52] Deike R and Schwerdtfeger K 1995 J. Electrochem. Soc. 142609

[53] Yanabe K, Akasaka M, Takeuchi M, Watanabe M, Narushima T and Iguchi Y 1997 Mater. Trans. JIM 38990

[54] Kalejs J P 1987 Silicon Processing for Photovoltaics II ed C P Khattak and K V Ravi (Amsterdam: Elsevier) p 185

[55] Bhihe C K, Mataga P A, Hutchinson J W, Rajendran S and Kalejs J P 1994 J. Cryst. Growth 13786

[56] Wallace L W, Sachs E and Hanoka J I 2003 Proc. 3rd WCPEC (Osaka) (Japan: WCPEC-3 Organising Committee, Arisumi Printing Inc.) p 1297

[57] Sachs E, Harvey D, Janoch R, Anselmo A, Miller D and Hanoka J I 2004 Proc. 19th EC PVSEC (Paris) at press

[58] Hahn G, Seren S, Sontag D, Schönecker A, Goris M, Laas L and Gutjahr A 2003 Proc. 3rd WCPEC (Osaka) (Japan: WCPEC-3 Organising Committee, Arisumi Printing Inc.) p 1285

[59] Hässler C, Hoefs H-U, Koch W, Stollwerk G, Mueller A, Karg D and Pensl G 2000 Mater. Sci. Eng. B 7139

[60] Kalejs J P 2004 Solid State Phenom. 95/96 159

[61] Chalmers B 1984 J. Cryst. Growth 703

[62] Koshka Y, Ostapenko S, Tarasov I, McHugo S and Kalejs J P 1999 Appl. Phys. Lett. 741555

[63] Ostapenko S, Tarasov I, Kalejs J P, Hässler C and Reisner E-U 2000 Semicond. Sci. Technol. 15840

[64] Möller H J, Funke C, Lawerenz A, Riedel S and Werner M 2002 Sol. Energy Mater. Sol. Cells 72403

[65] Werner M, Scheerschmidt K, Pippel E, Funke C and Möller H J 2004 Phys. Conf. Ser. 18065

[66] Knobloch K, Kittler M and Seifert W 2003 J. Appl. Phys. 931069

[67] Kittler M, Seifert W, Arguirov T, Tarasov I and Ostapenko S 2002 Sol. Energy Mater. Sol. Cells 72465

[68] Bailey J, McHugo S, Hieslmair H and Weber E W 1996 J. Electron. Mater. 251417

[69] Bailey J and Weber E R 1993 Phys. Status Solidi a 137515

[70] Pivac B, Amiotti M, Borghesi A, Sassella A and Kalejs J 1992 J. Appl. Phys. 713785

[71] Kalejs J P, Ladd L A and Gösele U 1984 Appl. Phys. Lett. 45268

[72] Kalejs J P, Jastrzebski L, Lagowski L, Henley W, Schielein D, Balster S G and Schroder D K 1994 Proc. 12th EC PVSEC (Amsterdam) (Bedford: HS Stephens) p 52

[73] Kalejs J P, Bathey B R, Borenstein J T and Stormont R W 1993 Proc. 23rd IEEE PVSC (Louisville) (US: IEEE, Library of Congress) p 184

[74] Mishra K 1996 Appl. Phys. Lett. 683281

[75] Klettke O, Karg D, Pensl G, Schulz M, Hahn G and Lauinger T 2001 Technical Digest 12th PVSEC (Jeju) (Seoul: International PVSEC-12) p 617

[76] Macdonald D, Cuevas A and Wong-Leung J 2001 J. Appl. Phys. 897932

[77] Cazcarra V and Zunino P 1980 J. Appl. Phys. 514206

[78] Kamiura Y, Hashimoto F and Yoneta M 1991 Phys. Status Solidi a 123357

[79] Karg D, Voigt A, Krinke J, Hässler C, Hoefs H-U, Pensl G, Schulz M and Strunk H P 1999 Solid State Phenom. 67/68 33

[80] Hässler C, Hoefs H-U and Thurm S 2000 Proc. 16th EC PVSEC (Glasgow) (London: James \& James) p 1352

[81] Gottschalk H 2000 Phys. Status Solidi b 222353

[82] Lu J, Rozgonyi G, Schönecker A and Gutjahr A 2004 Appl. Phys. Lett. submitted 
[83] McHugo S, Thompson A C, Mohammed A, Lamble G, Perichaud I, Martinuzzi S, Werner M, Rinio M, Koch W, Hoefs H-U and Hässler C 2001 J. Appl. Phys. 894282

[84] Buonassisi T, Vyvenko O F, Istratov A A, Weber E R, Hahn G, Sontag D, Rakotoniaina J P, Breitenstein O, Isenberg J and Schindler R 2004 J. Appl. Phys. 951556

[85] Sontag D, Hahn G, Geiger P, Fath P and Bucher E 2002 Sol. Energy Mater. Sol. Cells 72533

[86] Hahn G, Sontag D and Hässler C 2002 Sol. Energy Mater. Sol. Cells 72453

[87] Breitenstein O, Langenkamp M and Rakotoniaina J P 2001 Solid State Phenom. 78/79 29

[88] Myers S M, Seibt M and Schröter W 2000 J. Appl. Phys. 883795

[89] Newman R C 2000 J. Phys.: Condens. Matter 12 R335

[90] Kang J S and Schroder D K 1989 J. Appl. Phys. 652974

[91] Hahn G, Jooss W, Spiegel M, Fath P, Willeke G and Bucher E 1997 Proc. 26th IEEE PVSC (Anaheim) (US: IEEE, Library of Congress) p 75

[92] Schröter W and Kühnapfel R 1990 Appl. Phys. Lett. 562206

[93] Ourmazd A and Schröter W 1984 Appl. Phys. Lett. 45781

[94] Joshi S M, Gösele U M and Tan T Y 1995 J. Appl. Phys. 773858

[95] Schindler R 1994 Solid State Phenom. 37/38 343

[96] Mahfoud K, Pivac B and Muller J C 1997 Sol. Energy Mater. Sol. Cells 46123

[97] Jooss W, Hahn G, Fath P, Willeke G and Bucher E 1998 Proc. 2nd WC PSEC (Vienna) (Ispra: European Commission) p 1689

[98] Bronner G B and Plummer J D 1985 Mater. Res. Soc. Symp. Proc. 3649

[99] Graff K 2000 Metal Impurities in Silicon-Device Manufacturing (Berlin: Springer)

[100] Jeong J-W, Rohatgi A, Rosenblum M D and Kalejs J P 2000 Proc. 28th IEEE PVSC (Anchorage) (US: IEEE, Library of Congress) p 83

[101] Rohatgi A, Yelundur V, Jeong J, Ebong A, Meier D, Gabor A M and Rosenblum M D 2000 Proc. 16th EC PVSEC (Glasgow) (London: James \& James) p 1120

[102] Geiger P, Hahn G, Fath P and Bucher E 2001 Proc. 17th EC PVSEC (Munich) (Munich: WIP) p 1715

[103] Geiger P, Kragler G, Hahn G, Fath P and Bucher E 2002 Proc. 29th IEEE PVSC (New Orleans) (US: IEEE, Library of Congress) p 186

[104] Yelundur V, Rohatgi A, Jeong J-W, Gabor A M, Hanoka J I and Wallace R L 2000 Proc. 28th IEEE PVSC (Anchorage) (US: IEEE, Library of Congress) p 91

[105] Geiger P, Kragler G, Hahn G, Fath P and Bucher E 2001 Proc. 17th EC PVSEC (Munich) (Munich: WIP) p 1754

[106] Geiger P, Kragler G, Hahn G and Fath P 2004 Sol. Energy Mater. Sol. Cells at press

[107] Balster S G, Schroder D K, Bailey J and Kalejs J P 1995 J. Appl. Phys. 77371

[108] Hahn G and Geiger P 2003 Progr. Photovolt. Res. Appl. 11341

[109] Möller H J, Ghosh M, Rinio M, Riedel S and Yang D 1995 Proc. 13th EC PVSEC (Nice) (Bedford: HS Stephens) p 1390

[110] O’Mara W C, Herring R B and Hunt L P 1990 Handbook of Semiconductor Silicon Technology (Park Ridge, NJ: Noyes Publication)

[111] Lu J, Wagener M, Rozgonyi G, Rand J and Jonczyk R 2003 J. Appl. Phys. 94140

[112] Pearton J, Corbett W and Stavola M 1992 Hydrogen in Crystalline Semiconductors (Berlin: Springer)

[113] Pankove J I and Johnson N M 1991 Hydrogen in Semiconductors (Boston, MA: Academic)

[114] Nickel N H 1999 Hydrogen in Semiconductors II (Boston, MA: Academic)

[115] Davis E A 1996 J. Non-Cryst. Solids 198-200 1

[116] Dube C and Hanoka J I 1984 Appl. Phys. Lett. 451135

[117] Vyvenko O F, Krüger O and Kittler M 2000 Appl. Phys. Lett. 76697

[118] Kaufman H R 1978 J. Vac. Sci. Technol. 15272

[119] Seager C H and Ginley D S 1981 J. Appl. Phys. 521050

[120] Hansen W L, Pearton S J and Haller E E 1984 Appl. Phys. Lett. 44606

[121] Elgamel H E, Barnett A M, Rohatgi A, Chen Z, Vinvkier C, Nijs J and Mertens R 1995 J. Appl. Phys. 783457

[122] Spiegel M 1998 Microwave Induced Remote Hydrogen Plasma (MIRHP) Passivation of Multicrystalline Silicon Solar Cells (Allensbach: UFO Atelier)

[123] Spiegel M, Hahn G, Jooss W, Keller S, Fath P, Willeke G and Bucher E 1998 Proc. 2nd WC PSEC (Vienna) (Ispra: European Commission) p 1685

[124] Lüdemann R, Hauser A and Schindler R 1998 Proc. 2nd WC PSEC (Vienna) (Ispra: European Commission) p 1638

[125] Sterling H F and Swann R C G 1965 Solid-State Electron. 8653

[126] Nagel H, Aberle A G and Hezel R 1998 Proc. 2nd WC PSEC (Vienna) (Ispra: European Commission) p 1422 
[127] Chow R, Lanford W A, Ke-Ming W and Rosler R S 1982 J. Appl. Phys. 535630

[128] Szlufcik J, De Clercq K, De Schepper P, Poortmans J, Buczkowski A, Nijs J and Mertens R 1994 Proc. 12th EC PVSEC (Amsterdam) (Bedford: HS Stephens) p 1018

[129] Cai L and Rohatgi A 1997 IEEE Trans. Electron Devices 4497

[130] Boehme C and Lucovsky G 2001 J. Vac. Sci. Technol. A 192622

[131] Stavola M, Jiang F, Rohatgi A, Kim D, Holt J, Atwater H and Kalejs J 2003 Proc. 3rd WCPEC (Osaka) (Japan: WCPEC-3 Organising Committee, Arisumi Printing Inc.) p 909

[132] Hahn G, Sontag D, Seren S, Schönecker A, Burgers A R, Ginige R, Cherkaoui K, Karg D and Charifi H 2004 Proc. 19th EC PVSEC (Paris) at press

[133] Aberle A 1999 Crystalline Silicon Solar Cells, Advanced Surface Passivation and Analysis (Sydney: Centre for Photovoltaic Engineering, University of New South Wales)

[134] Duerinckx F and Szlufcik J 2002 Sol. Energy Mater. Sol. Cells 72231

[135] Rizk R, de Mierry P, Ballutaud D, Aucouturier M and Mathiot D 1991 Phys. Rev. B 446141

[136] Hansen W L, Haller E E and Luke P N 1982 IEEE Trans. Nucl. Sci. 29738

[137] Higgs V and Kittler M 1993 Appl. Phys. Lett. 632085

[138] Hahn G, Geiger P, Fath P and Bucher E 2000 Proc. 28th IEEE PVSC (Anchorage) (US: IEEE, Library of Congress) p 95

[139] Möller H J 1993 Semiconductors for Solar Cells (Norwood: Artech House Publishers)

[140] Pernau T, Hahn G, Spiegel M and Dietsche G 2001 Proc. 17th EC PVSEC (Munich) (Munich: WIP) p 1764

[141] Nakayashiki K, Kim D S, Rohatgi A and Bathey B R 2004 Technical Digest 14th PVSEC (Bangkok) (Bangkok: Krissanapong Kirtikara) p 643

[142] Hanoka J I, Seager C H, Sharp D J and Panitz J K G 1983 Appl. Phys. Lett. 42618

[143] Jeong J-W, Rosenblum M D, Kalejs J P and Rohatgi A 2000 J. Appl. Phys. 877551

[144] Karg D, Pensl G and Schulz M 2003 Proc. 3rd WCPEC (Osaka) (Japan: WCPEC-3 Organising Committee, Arisumi Printing Inc.) p 1112

[145] Yelundur V, Rohatgi A, Jeong J W and Hanoka J I 2002 IEEE Trans. Electron Devices 491405

[146] Jeong J-W, Cho Y H, Rohatgi A, Rosenblum M D, Bathey B R and Kalejs J P 2002 Proc. 29th IEEE PVSC (New Orleans) (US: IEEE, Library of Congress) p 250

[147] Sopori B L, Deng X, Benner J P, Rohatgi A, Sana P, Estreicher S K, Park Y K and Roberson M A 1996 Sol. Energy Mater. Sol. Cells 41/42 159

[148] Van Wieringen A and Warmoltz N 1956 Physica 22849

[149] Kim D S, Gabor A M, Yelundur V, Upadhyaya A D, Meemongkolkiat V and Rohatgi A 2003 Proc. 3rd WCPEC (Osaka) (Japan: WCPEC-3 Organising Committee, Arisumi Printing Inc.) p 1467

[150] Hahn G, Geiger P, Sontag D, Fath P and Bucher E 2002 Sol. Energy Mater. Sol. Cells 7457

[151] Karg D, Charifi H, Pensl G, Schulz M and Hahn G 2004 Proc. 19th EC PVSEC (Paris) at press

[152] Estreicher S K, Hastings J L and Fedders P A 1998 Phys. Rev. B 57 R12663

[153] Estreicher S K, Hastings J L and Fedders P A 1999 Mater. Sci. Eng. B 5831

[154] Estreicher S K, Wells K, Fedders P A and Ordejon P 2001 J. Phys.: Condens. Matter 136271

[155] Sopori B 2003 J. Electron. Mater. 321034

[156] Sopori B, Zhang Y and Reedy R 2002 Proc. 29th IEEE PVSC (New Orleans) (US: IEEE, Library of Congress) p 222

[157] Estreicher S K, Park Y K and Fedders P A 1996 Early Stages of Oxygen Precipitation in Silicon ed R Jones (Dordrecht: Kluwer) p 179

[158] Stein H J and Hahn S K 1994 J. Appl. Phys. 753477

[159] Johnson N M and Hahn S K 1986 Appl. Phys. Lett. 48709

[160] Bruton T 2002 Sol. Energy Mater. Sol. Cells 723

[161] Kränzl A, Kopecek R, Peter K, Rüland E and Fath P 2004 Proc. 19th EC PVSEC (Paris) at press

[162] Goris M J A A, Weeber A W, Jooss W and Huster F 2001 Proc. 17th EC PVSEC (Munich) (Munich: WIP) p 1535

[163] Hahn G, Zechner C, Spiegel M, Jooss W, Fath P, Willeke G and Bucher E 1998 Proc. 2nd WC PSEC (Vienna) (Ispra: European Commission) p 1840

[164] Hahn G, Hässler C and Langenkamp M 2001 Proc. 17th EC PVSEC (Munich) (Munich: WIP) p 1371

[165] Rohatgi A and Jeong J W 2003 Appl. Phys. Lett. 82224

[166] Hahn G, Geiger P and Schubert G 2004 Proc. 19th EC PVSEC (Paris) at press

[167] Rohatgi A, Kim D S, Yelundur V, Nakayashiki K, Upadhyaya A, Hilali M and Meemongkolkiat V 2004 Technical Digest 14th PVSEC (Bangkok) (Bangkok: Krissanapong Kirtikara) p 635

[168] Rohatgi A, Yelundur V, Jeong J-W, Kim D S and Gabor A M 2003 Proc. 3rd WCPEC (Osaka) (Japan: WCPEC-3 Organising Committee, Arisumi Printing Inc.) p 1352 
[169] Rohatgi A, Kim D S, Nakayashiki K, Yelundur V and Rounsaville B 2004 Appl. Phys. Lett. 84145

[170] Damiani B, Nakayashiki K, Kim D S, Yelundur V, Ostapenko S, Tarasov I and Rohatgi A 2003 Proc. 3rd WCPEC (Osaka) (Japan: WCPEC-3 Organising Committee, Arisumi Printing Inc.) p 927

[171] Schmidt W, Woesten B and Kalejs J P 2002 Progr. Photovolt. Res. Appl. 10129

[172] Hahn G and Gabor A M 2003 Proc. 3rd WCPEC (Osaka) (Japan: WCPEC-3 Organising Committee, Arisumi Printing Inc.) p 1289

[173] Gerhards C, Fischer A, Spiegel M, Fath P, Bucher E, Leifhelm B and Weck M 2001 Proc. 17th EC PVSEC (Munich) (Munich: WIP) p 1747

[174] Hahn G, Zechner C, Rinio M, Fath P, Willeke G and Bucher E 1999 J. Appl. Phys. 867179

[175] Seren S, Hahn G, Gutjahr A, Burgers A R and Schönecker A 2004 Proc. 31 st IEEE PVSC (Lake Buena Vista) (US: IEEE, Library of Congress) at press

[176] Alsema E A and de Wild-Scholten M J 2004 Proc. 19th EC PVSEC (Paris) at press 